\title{
EL DISCURSO DE LA DESUNIÓN: LA DISPUTA JURISDICCIONAL POR LAS LIMOSNAS DE LA VIRGEN DE GUADALUPE EN NUEVA ESPAÑA, 1572-1607*
}

\author{
A DISCOURSE OF SEPARATION: A JURISTICTIONAL DISPUTE \\ OVER THE ALMS OF THE VIRGIN OF GUADALUPE \\ IN NEW SPAIN, 1572-1607
}

\author{
Lidia E. Gómez García \\ Benemérita Universidad Autónoma de Puebla \\ Facultad de Filosofía y Letras \\ Colegio de Historia \\ tepontla.cholula@gmail.com

\section{Eduardo Ángel Cruz} \\ Centro de Investigación y Docencia Económicas \\ División de Historia
}

\section{Resumen}

Esta investigación estudia el conflicto jurisdiccional por la recaudación de limosnas de la virgen de Guadalupe entre los frailes franciscanos, los procuradores jerónimos y el arzobispado mexicano desde 1556 hasta 1606. Bajo el presupuesto metodológico de que toda recaudación (incluida la limosna) constituía un acto político en la monarquía hispana, se analizan los procesos legales suscitados en 1556, 1562, 1572 y 1606 sobre el establecimiento y la administración del culto guadalupano en la Nueva España. Estos debates jurídicos indican que el conflicto de demanda de limosnas fue un factor de consideración para el surgimiento del discurso sagrado aparicionista de mediados del siglo xvir. Entonces éste es no sólo un manifiesto de la devoción guadalupana sino también un argumento jurídico que terminó por hacer irreductible la brecha entre una y otra mariofanía.

Palabras clave: limosnas, virgen de Guadalupe, devoción, mariofanía, procuradores, cuestores.

\footnotetext{
Abstract

This article analyzes the conflict for Virgin of Guadalupe's jurisdiction of alms recollection between the Franciscan friars, the procurators of Saint Jerome, and the archbishop of Mexico, since 1556 until 1606. Under the methodological presumption that all recollection of alms constituted a political act in the Spanish Monarchy, this article examines the legal procedures that took place in 1556,1562, 1572 and 1606 regarding the establishment and administration

* Agradecemos al Seminario Creencias y Prácticas Religiosas en Nueva España, siglos Xvi al XVIII, del Instituto de Investigaciones Históricas de la UNAM, en especial a su coordinadora Gisela von Wobeser, por sus comentarios a este trabajo. Asimismo, expresamos nuestro agradecimiento a David Carbajal López por sus sugerencias y comentarios.
} 
of the cult of Guadalupe in New Spain. These juridical debates indicate that the conflict for jurisdiction was a factor for the emergence of the Virgin of Guadalupe's sacred narrative around middle seventeenth century, not only as the result of devotion to Guadalupe, but also as a juridical and theological argument that made eventually irreducible the gap between the Virgin of Extremadura and of Tepeyac.

Keywords: alms, Virgin of Guadalupe, devotion, mariophany, procurators, quaestors.

Información del artículo

Recibido: 17 de enero de 2018.

Aceptado: 26 de septiembre de 2018.

DOI: 10.22201/iih.24486922e.2019.61.63139

La historiografía guadalupana, una de las más difundidas, ha concentrado la mayor parte de sus esfuerzos en atender dos de los momentos clave del desarrollo del culto mariano: el origen aparicionista del culto -o su refutaciónentre 1531-1556 ${ }^{1}$ y, por otro lado, la consolidación criolla de su patronato en Nueva España en $1754 .^{2}$ Ambas posturas han brindado considerables aportes que, a pesar de sus diferencias, coinciden en señalar que el culto guadalupano del periodo novohispano impregnó desde su origen una proto-religiosidad católica mexicana, ${ }^{3}$ dando por sentado que las características del culto a la virgen de Guadalupe estuvieron presentes desde el momento mismo del hallazgo de sus primeros testimonios hacia mediados del siglo xvi. Sin embargo, estudios recientes han mostrado que la historia del culto guadalupano constituyó más bien un disputado, conflictivo y negociado proceso de establecimiento devocional con características coyunturales específicas. ${ }^{4}$

En este artículo pretendemos introducir al debate guadalupano un aspecto político-jurídico poco atendido en la historiografía. Nos referimos al conflicto jurisdiccional por el control de las limosnas de la virgen de Guadalupe entre los procuradores del Monasterio de Guadalupe de Extremadura y las autoridades seculares de la Nueva España en la ciudad de México, que tendría su primera data en la década de 1570 y continuaría en la primera

${ }^{1}$ La extensa historiografía sobre el tema nos impide citar los estudios más relevantes so pena de omitir irremediablemente algunos, por lo que señalamos solamente los que constituyen lecturas obligadas, entre otros: De la Maza (1981); O’Gorman (2016); Miranda Godínez (2001); Noguez (1995).

${ }^{2}$ En el mismo tenor que la cita anterior, véase Escamilla González (2000, pp. 199-232); Brading (1997); Calvo (1997).

${ }^{3}$ Escamilla González (2010, p. 230).

${ }^{4}$ Martínez Baracs (2007, pp. 43-72); (2015, pp. 315-331); (2003, pp. 291-305). 
década del siglo XVII. ${ }^{5}$ La historiografía sobre este tema parece dejar de lado un par de eventos hasta ahora considerados colaterales que, sin embargo, pensamos, constituyen el elemento central del conflicto. Hablamos de la recolección de limosnas por parte de la curia entre los pueblos de indios -que se hallaban dentro de la jurisdicción de las órdenes religiosas-, y la posterior intervención de un actor aparentemente ajeno al debate por competencias entre clero secular y regular: un demandador jerónimo de Guadalupe de nombre fray Diego de Santa María. ${ }^{6}$

En este artículo proponemos que la recaudación de limosnas es un aspecto de fundamental importancia en el sostenimiento de todas las devociones de la monarquía católica y, por lo tanto, estas últimas no pueden ser analizadas sin considerar el estudio de las aportaciones que sustentaban los cultos. En este caso, centramos el estudio en el conflicto por privilegios reales sobre esas recaudaciones que enmarcó el desarrollo de la devoción guadalupana desde la década de 1550 hasta la primera mitad del siglo XVII. Nuestra contribución a este debate historiográfico propone que fue este conflicto de jurisdicción de recaudación sobre limosnas y obras pías el fundamento de la separación entre la virgen de Guadalupe de Extremadura y la del Tepeyac, y lo que originó gran parte de la literatura aparicionista hacia mediados del siglo XVII, que posteriormente se perpetuó en el recurso literario que ha nutrido las reivindicaciones devocionales nacionalistas en las siguientes centurias.

Antecedentes: distintas imágenes, una misma jurisdicción

Durante los siglos XV y XVI no existió una diferenciación tópica que distanciara las variadas representaciones marianas que ostentaron el genitivo "Guadalupe".

${ }^{5}$ En esta investigación entendemos el término jurisdicción como la serie de privilegios reales otorgados a las corporaciones religiosas (clero secular y regular, así como cofradías, etcétera) para la colecta de limosnas en un territorio establecido o a una devoción particular. En ese sentido, estas jurisdicciones necesariamente se traslapaban en ciertos contextos, lo que generó diversos conflictos por competencias recaudatorias. Véase Aldana Rivera (2006, pp. 44-45).

${ }^{6}$ En este caso, el título "demandador" se deriva del poder que tenían estos agentes para cobrar las "demandas" que los fieles hacían a la virgen de Guadalupe, véase Peterson (2014, p. 41). Otros autores los señalan simplemente como "organizadores de devociones y recolectores de limosnas" o agentes que "venían a recolectar limosnas y a fomentar la devoción hacia la virgen de Guadalupe de Extremadura”. Véanse Eichmann-Oehrli (2004, pp. 71-88); Sigaut (2012, p. 444). Para otros casos de demanda de limosna y demandadores, véanse Moro Romero (2012, pp. 115-172); Barral (1998, pp. 7-33). 
Es decir, todas aquéllas eran consideradas vehículos terrenales de un mismo manifiesto divino, la virgen María en su advocación de Guadalupe. Así queda patente cuando uno de sus apologistas aseveraba que "aunque todas las imágenes de la Madre de Dios representan una misma señora y original: quiere nuestro Señor mostrarse maravilloso por sus secretos juicios en esta [la virgen de Guadalupe], que significan lo mismo". ${ }^{7}$ Esto no quiere decir que sus representaciones carecieran de características locales propias. Por el contrario, de la misma manera como se dio la integración de distintos reinos a la monarquía, ${ }^{8}$ cada provincia, ciudad o villa ibérica se apropió discursivamente de una advocación mariana y la empleó para obtener preminencia local una vez que se hallasen éstos bajo su protección divina. ${ }^{9}$

Esta vinculación entre la devoción a María y la preeminencia de su protección divina a los proyectos monárquicos permitió que se gestara el patronato del rey Alfonso XI de Castilla de la advocación de María de Guadalupe, en el año de 1340. Según la tradición, había existido una primera imagen de bulto de la virgen María elaborada por San Lucas desde siglos tan tempranos como el viII, momento en que coincidentemente ocurrió la "invasión" musulmana a la península ibérica. Gregorio Magno había regalado esta imagen al obispo Leandro de Sevilla, con el fin de que éste la resguardase y la alejase del peligro infiel. ${ }^{10}$ La imagen fue luego enterrada durante largas centurias y allí permaneció hasta que la cristiandad, encabezada por Alfonso XI, recuperó estas tierras. Inmediatamente después de este hecho tuvo lugar la mariofanía que dio origen al culto en los márgenes del río de Guadalupe, lo que constituiría una tradición que legitimó jurídicamente, a través de una manifestación divina, la conquista, la ocupación y la posesión de los territorios que habían sido arrebatados a los infieles en guerra justa por el monarca castellano. ${ }^{11}$

Como se puede anticipar, el discurso monárquico de re-ocupación militar y éste de re-aparición mariana se vieron prontamente complementados.

${ }^{7}$ Montalvo (1631, f. 18v). Énfasis nuestro.

${ }^{8}$ Sigaut (2012, pp. 437-439).

${ }^{9}$ Nebel (1995, pp. 52-53).

${ }^{10}$ Nebel (1995, pp. 53-54).

${ }^{11}$ Nótese la similitud en las narrativas de la aparición: al vaquero Gil Cordero se le había manifestado la virgen María para decirle que su pintura se hallaba enterrada en aquel lugar de la provincia de Cáceres; por esta razón, le fue solicitado que diera este mensaje ante las autoridades eclesiásticas de la región para que sacasen a la Virgen de allí y le pusiesen un templo digno. Luego esta advocación de María, como era uso y costumbre en la tradición jurídico-canónica hispana, ganó el posterior nombre de Nuestra Señora de Guadalupe, debido a la tierra que la había visto "re-aparecer". Véase Fuentes Nogales (2008, pp. 508-509). 
Por esta razón, el monarca castellano asignó la iglesia de las Villuercas —en donde había ocurrido el milagro de reaparición de la Virgen-a la administración del arzobispado de Toledo a sugerencia del cardenal Gil Álvarez de Albornoz. ${ }^{12}$ Acorde con esta coyuntura político-religiosa, el rey se convirtió en el principal benefactor del culto a Guadalupe y, como tal, comenzó a sostenerlo a través de las rentas de su real patrimonio. Empero, mientras el rey castellano emprendía su proceso de centralización militar, debió notar prontamente que no podría mantener de forma permanente erogaciones destinadas a la iglesia de Guadalupe. Estos recursos serían considerados de mayor utilidad en las acciones bélicas de defensa de la cristiandad, que poco a poco se iba convirtiendo en el más grande de los compromisos financieros de la Corona.

Por esta razón, el soberano castellano cambió la administración de las rentas de la iglesia dotándola de un privilegio real perpetuo que le permitiera sostenerse de forma autónoma y, al mismo tiempo, dar cumplimiento a la obligación a la cual se había suscrito el rey al ser nombrado patrón de la citada devoción. El privilegio real al que nos referimos es la exclusividad de recaudación de limosnas dedicadas a nombre de la virgen de Guadalupe que tuviera lugar en su jurisdicción eclesiástica, así como la capacidad de intervenir a través de cuestores nombrados con la finalidad de "demandar" lo que le correspondía al privilegio fiscal, según un decreto de $1348 .{ }^{13}$ Posteriormente, en aras de velar este privilegio, el rey trasladó la adscripción eclesiástica del santuario de secular a regular, otorgando el ejercicio del monopolio del culto de Guadalupe a la Orden de San Jerónimo, junto con los citados privilegios de cuestura. Por esta razón, a partir de 1389 y hasta periodos tan tardíos como el siglo xIx, la orden de monjes jerónimos preservó el culto a Santa María de Guadalupe y su santuario, junto al cual construyeron su famoso Monasterio Real. ${ }^{14}$

Los frailes jerónimos lograron ampliar posteriormente sus prerrogativas de cuestura a través de un singular argumento legal: equipararon su labor religiosa con el concepto jurídico de "bien común" del reino. De esta manera consiguieron elevar la calidad jurídica de sus recaudaciones de simples exacciones voluntarias a contribuciones de carácter obligatorio. Así lo deja ver el historiador fray Gabriel de Talavera, prior de la casa

${ }^{12}$ Fernández Sánchez (1994, p. 61).

${ }^{13}$ Peterson (2014, p. 41). Agradecemos a Bárbara E. Mundy y a Savannah Esquivel su recomendación y generoso apoyo.

${ }^{14}$ Nebel (1995, pp. 53-54). 
de Guadalupe, cuando al hablar del origen de las limosnas que se piden a nombre de Nuestra Señora de Guadalupe en el primer libro apologético de la historia de la Virgen menciona que esta entrega había dejado de ser de hace tiempo de mera piedad a ser, en todo el reino, "más aún como deuda y legado forzoso en las disposiciones y últimas voluntades de los difuntos". ${ }^{15}$

Es importante señalar la decisiva notoriedad de estos privilegios jurídicos: licencia para cobro de limosnas y cobijo del patronato regio. Tal circunstancia se evidenció en el posterior desarrollo del Monasterio de Guadalupe durante el siglo siguiente, es decir, el siglo xv, cuando llegó a ostentar el prestigio de ser uno de los conventos más grandes, ricos y ornamentados de toda la Iberia, ${ }^{16}$ además de uno de los centros de $\operatorname{arte}^{17} \mathrm{y}$ de cultura más ricos de la región. ${ }^{18}$ Este éxito explica la consecuente expansión devocional $-\mathrm{y}$ jurisdiccional-que gozó Guadalupe en los demás reinos peninsulares, adonde muchos de sus devotos llevaron copias de la imagen autorizadas por el monasterio. Consecuentemente, los meticulosos monjes jerónimos dedicaron mayores esfuerzos a ejercer los privilegios recaudatorios de las rentas y las limosnas que se derivaban de la expansión de su devoción, para lo cual desplegaron un circuito complejo de agentes recaudadores, cuestores o procuradores a lo largo de las vastas posesiones regias por donde se extendió el culto durante la segunda mitad del siglo Xv. ${ }^{19}$ Cabe recordar que al ser Guadalupe una devoción protegida por patronato regio gozaba de una jurisdicción amplia para poder realizar sus recaudaciones. Por lo tanto, sus demandadores no eran nada más religiosos itinerantes, sino oficiales con atribuciones de recaudación real. Este ejercicio de cuestura de limosna permitió, entre 1524 y 1527, que el monasterio extremeño

15 Talavera (1597, f. 452v); Peña (2007). El historiador dedica un apartado entero en el tratado tercero de su obra, sobre algunas "Observaciones a la Historia de Nuestra Señora de Guadalupe”, al origen de las limosnas que se pedían para la virgen de las Villuercas. Esto debido a las críticas que se hicieron en su momento a su orden sobre que un monasterio tan ostentoso como el guadalupano no debía utilizar un recurso como la demanda de limosnas, pues esta era una herramienta de pobres vergonzantes. Con el argumento jurídico del bien común del reino, el autor desestima las críticas de sus detractores.

${ }^{16}$ Montalvo (1631, f. 15r-15v).

17 Peterson (2014, p. 49).

${ }_{18}$ Nebel (1995, p. 54).

${ }^{19}$ Las categorías empleadas se utilizan en la documentación de la época. En la correspondencia de algunos de estos personajes se emplea la palabra "demandadores", es decir, término administrativo similar al del antiguo oficio de cuestores romanos; mientras tanto, en cédulas reales, aparecen como "procuradores", esto es, abogados y representantes legales del convento. 
percibiera una tercera parte del total de sus ingresos conventuales solamente del beneficio de dicho privilegio. ${ }^{20}$

Bajo esta circunstancia jurídica podemos situar al culto guadalupano y sus formas de recaudación hacia los albores del siglo Xvi. Por esta razón, no resulta sorprendente el enorme interés que pondrían los monjes jerónimos en hacer valer sus prebendas una vez que se enterasen - a través de sus extensos circuitos de comunicación- de que en Indias se habían establecido iglesias, ermitas y otras formas del culto a Guadalupe que se hallaban fuera de su bien establecido control recaudatorio. Como era de esperarse, estos frailes terminarían apelando legalmente a sus derechos - por ejemplo, el ser culto regio por haber prestado servicio espiritual a la empresa monárquica de la reconquista-, para obtener los permisos necesarios con los cuales nombrar agentes para incursionar en los mencionados territorios indianos en busca del culto a la virgen de Guadalupe y las limosnas que generaba. Esto los llevaría, en la década de 1570, a incorporarse a las dinámicas políticas que ocurrían en los reinos del Perú y, especialmente, en el de la Nueva España, asunto que atendemos en el siguiente apartado.

La competencia sobre los privilegios recaudatorios de limosnas

El 6 de septiembre de 1556, el recientemente incorporado arzobispo de México fray Alonso de Montúfar iniciaría un debate sobre el culto de Guadalupe, ${ }^{21}$ una vez que pronunciara su célebre sermón en la Catedral de México que llevaría por título Beati oculi qui vident quae vos videtis. ${ }^{22} \mathrm{La}$ historiografía ha señalado que la exposición del prelado había buscado restarle poderío político a los franciscanos, al dirigir su oratoria sagrada hacia el grupo que les brindaba mayor legitimidad: los indios circunvecinos de la ciudad de México. ${ }^{23}$ En ese sermón, el prelado había promovido la devoción a la virgen de Guadalupe destacando su fama de ser muy milagrosa, por lo cual sugirió a su feligresía seguir el ejemplo puesto por los indios, confiarse a su cuidado y continuar con esta tradición. ${ }^{24}$ Prontamente las declaraciones de Montúfar serían rebatidas con enorme agudeza doctrinal

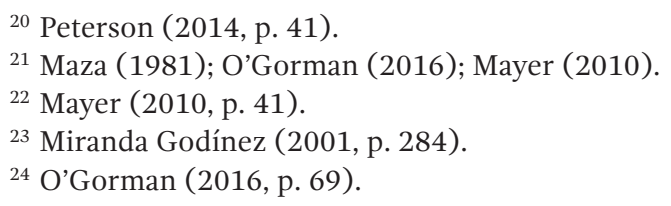


por el provincial y destacado predicador fray Francisco de Bustamante, el día 8 de septiembre del mismo año, ${ }^{25}$ en otro sermón correspondiente al día de la festividad de la Natividad de la virgen María. Bustamante, frente a las autoridades civiles más importantes del virreinato, hizo serias acusaciones en contra del dominico, entre ellas el excitar a los indios a la idolatría, así como predicar y dar por ciertos milagros no comprobados o falsos; ${ }^{26}$ contraviniendo así con los postulados acordados en el Primer Concilio Provincial. ${ }^{27}$ De estos alegatos se desprendería, luego, el primer y más importante corpus documental que nos permite a los historiadores reconstruir este hecho: las Informaciones de $1556,{ }^{28}$ mandadas a levantar por el mismo arzobispo Montúfar.

Los testimonios judiciales de varios testigos presenciales, realizados en 1556, nos dan cuenta de que el sermón del arzobispo Montúfar buscaba promover la devoción a la virgen entre la feligresía española que asistió a la catedral. ${ }^{29}$ Es de destacar que los testigos de esta Información eran hispanos y prominentes devotos de la virgen de Guadalupe, quienes "en toda la mayor parte de esta ciudad ha visto este testigo que ha tenido y tiene devoción y han ocurrido a ella [la virgen de Guadalupe] con sus limosnas y oraciones". ${ }^{30}$ Por el testimonio del abogado de la Real Audiencia, el bachiller Francisco de Salazar, sabemos que una de las razones de la promoción de la devoción tenía como antecedente que el Tepeyac era un sitio de esparcimiento especialmente concurrido por los españoles, ${ }^{31}$ por lo que defendieron su derecho a ir a un pueblo de indios a venerar a la virgen: "aunque pese a Bustamante, hemos de ir a servir a Nuestra Señora dondequiera que su Imagen esté, y contradiga él [fray Francisco de Bustamante] la devoción cuanto quisiere, que antes es dar a entender que le pesa de que vayan españoles allí, de aquí adelante, si íbamos una vez iremos cuatro". ${ }^{22}$ No es de sorprender, por lo

${ }^{25}$ O’Gorman (2016, p. 50).

${ }^{26}$ Miranda Godínez (2001, p. 241).

${ }^{27}$ Mayer (2002, pp. 17-49).

${ }^{28}$ Informaciones de 1556, en Proyecto Guadalupe.com (en adelante, Informaciones).

${ }^{29}$ Herrejón Peredo (2003, p. 18); Mayer (2002, p. 23).

${ }^{30}$ Testimonio de Juan de Salazar, procurador de la Real Audiencia, Informaciones, f. 13v.

${ }^{31}$ Testimonio del bachiller Francisco de Salazar, Abogado de la Real Audiencia, Informaciones, f. $14 \mathrm{r}$.

32 Testimonio del bachiller Francisco de Salazar, abogado de la Real Audiencia, Informaciones, f. 15r. Otro testimonio relevante es el de Bernal Díaz del Castillo, que señala la devoción a la Virgen como una de las grandezas de los españoles en la Nueva España. Véase Torre Villar y Navarro de Anda (1999, p. 147). 
tanto, que los mismos testigos pusieran sobre la mesa el tema de las limosnas, especialmente aludiendo a lo argumentado por fray Francisco de Bustamante sobre que "la limosna que se daba fuera mejor darla a pobres vergonzantes que hay en esta ciudad, y aún que no se sabía en qué se gastaba". ${ }^{3}$

Es precisamente por el tema de licencias para recolección de limosnas que consideramos insostenible la tesis de que el culto guadalupano en la Nueva España fuera sustentado por los indios antes de la intervención de Montúfar, ya que en ese caso habría estado bajo administración de los frailes franciscanos. Si consideramos que la cofradía de indios sólo fue fundada hasta la segunda mitad del siglo XVII, mientras que la de españoles desde la primera mitad del XVI, surge la duda sobre la temprana devoción india en dicha centuria. Las fuentes documentales en náhuatl sólo registran el culto a partir de 1555-1556, con la procesión del traslado de la imagen y el debate entre el sermón de Montúfar y el franciscano Bustamante. Chimalpáhin registra en sus anales que en el año de 1556 "Nuestra querida madre Santa María de Guadalupe fue mostrada en el Tepeyac". ${ }^{34}$ En un sentido similar, evidencia de que fue un evento importante para los indios, registran el suceso los Anales de Juan Bautista: "en el año de 1555 entonces fue mostrada Santa María de Guadalupe, allá en Tepeyacac”. ${ }^{35}$ En ambos casos, el verbo en náhuatl usado para describir el evento es neci, que no se refiere a "apariciones" sobrenaturales de imágenes religiosas, sino a manifestar, mostrar, hacer público (p. 54). Pese a que los anales no registran una mariofanía en el Tepeyac, sí son un testimonio "al hecho de que en 1555 cobra auge el culto guadalupano", que pudo o no tener ya un antecedente (pp. 54-55). Es decir, los testimonios nahuas registran que a partir de esa fecha se inició formalmente la tradición de una fiesta religiosa a la advocación de la Virgen, que tiene su origen en los grandes preparativos para el traslado de la imagen de catedral a la ermita del Tepeyac, siguiendo los lineamientos del Primer Concilio Mexicano, y que implican la dotación de limosna en especie y trabajo, elemento fundamental para entender la importancia en el impulso de tal devoción. Por otro lado, el

${ }^{33}$ Testimonio del bachiller Francisco de Salazar, abogado de la Real Audiencia, Informaciones, f. 14r-14v. La intención de estas Informaciones no tenía como fin principal indagar el nivel de devoción guadalupana entre los indios, sino desmentir las acusaciones contra el arzobispo Montúfar, que consistían esencialmente en la incitación idolátrica entre la población natural y la jura de milagros no comprobados.

${ }^{34}$ Véase Chimalpahin Cuauhtlehuanitzin (1889, p. 252); Nebel (1995, pp. 137-138).

${ }^{35}$ Véase Reyes García (2001, p. 160). 
argumento de una devoción india sustentado en los anales poblanos presenta la interrogante sobre el hecho de que no todas las copias tienen ese dato, además de que esos registros fueron elaborados a partir de la segunda mitad del siglo XVII, cuando el debate aparicionista estaba en su apogeo. ${ }^{36}$ Por otro lado, dentro del abundante corpus de sermones y retórica cristiana traducida por los frailes y sus discípulos indios, no existe uno dedicado o donde se mencione a la virgen de Guadalupe del Tepeyac. El fraile Pedro Oroz, escribió y tradujo siete sermonarios en lengua nativa con el objetivo de ayudar en la prédica a los indios, para cada fiesta religiosa del año litúrgico, del cual dedicó uno a las fiestas de la virgen María en todas sus advocaciones. Entre esos sermonarios no se encuentra uno dedicado a la virgen de Guadalupe, mucho menos a la venerada en el Tepeyac.

Desde el punto de vista de la administración hispana, en ninguno de los procesos judiciales del siglo Xvi hay testimonio de devoción de los indios a la Virgen en 1531, menos aún a la mariofanía, lo que no descarta la posibilidad de que haya sucedido. Esto tampoco excluye la existencia temprana de narrativas de mariofanías, sino que evidencia que nunca fueron usadas en proceso jurídico o debate argumentativo hasta el siglo Xvir en que fue impreso el Nican mopohua. Asimismo, sorprende que no haya registro de procesos judiciales del pueblo y villa del Tepeyac, sino justamente hasta la segunda mitad del siglo XVII. ${ }^{37}$

Recordemos que la ermita del Tepeyac no era la única ubicada en pueblo de indios y sostenida por devotos españoles, puesto que le antecedía desde el momento de la conquista la de la virgen de los Remedios en Tacuba, donde también hubo conflicto con agustinos y franciscanos por motivos similares. ${ }^{38}$ En ambos casos, la aparición de la virgen a un indio fue el fundamento para el establecimiento de una ermita en un pueblo de indios, mientras que la devoción española lo era para la administración del culto por el clero secular.

En ese sentido, el arzobispo Montúfar no estaba reconociendo en su homilía la devoción de los naturales a aquella milagrosa virgen, ${ }^{39}$ sino promo-

${ }^{36}$ Veánse Anales del barrio de San Juan del Río (2000); Gómez García (2018, pp. 314-325).

${ }^{37}$ Véase Juárez (2018, pp. 43-46).

${ }^{38}$ Miranda Godínez (2001, p. 62). La narrativa de esta devoción también señala la aparición de la imagen a un indio cacique, lo que coincidirá después con la oratoria sagrada sobre el milagro guadalupano. En ambos casos los conflictos se centrarán precisamente en ser devociones españolas en pueblos de indios.

${ }^{39}$ Ejemplo de otro impulso a la devoción a la virgen de Guadalupe entre los indios, en el siglo Xvi, fue la que se promovió en el septentrión de la Nueva España por el ermitaño Gregorio López, quien había encontrado justamente en la imagen de la virgen de Guadalupe 
viéndola entre su feligresía hispana, lo que significaba incrementar las limosnas y obras pías. Si en su célebre sermón el prelado alabó la participación de los indios en ese culto fue con el fin de resaltar su aporte durante la procesión del traslado de la imagen a instancias del prelado (registrado por Chimalpáhin y en los Anales de Juan Bautista). ${ }^{40} \mathrm{Al}$ incorporar a los indios en el sustento del culto a la virgen de Guadalupe, el clero diocesano se había beneficiado del servicio personal y el cobro de limosnas de los indios sin transgredir las jurisdicciones eclesiásticas de los franciscanos, protegidas por disposiciones reales ${ }^{41}$ lo que provocó la reacción inmediata de los frailes.

En ese sentido, si bien el desarrollo del culto a la virgen de Guadalupe se insertó en una disputa política entre los franciscanos y el clero diocesano, consideramos que el sermón del dominico conformaba una estrategia de fortalecimiento del clero secular, al incorporar el cobro de limosnas a los indios justo en un momento en que el tributo y el diezmo eran motivo de importantes debates y conflictos. ${ }^{42}$ Dado que la iniciativa del prelado de cobrar diezmo a los naturales se había visto constantemente frustrada, la estrategia de recaudación piadosa vendría a solventar de cierta manera este déficit administrativo, asegurándole a la curia metropolitana una mayor presencia entre aquel sector que los frailes mantenían bajo su cura de almas. ${ }^{43}$ Esta circunstancia no era excepcional en el contexto de las competencias por las limosnas en las Indias Occidentales; al contrario, era un asunto bastante común y conocido por las altas esferas eclesiásticas. ${ }^{44}$

de Extremadura la vocación religiosa que lo condujo a Nueva España. Véase Ocaranza (1944, pp. 19, 45 y 172).

${ }^{40}$ A esta estrategia contribuía de manera eficiente la tradición ritual y religiosa de los indios, quienes integraron las devociones marianas asombrosamente rápido desde la primera mitad del siglo XVI. Véase Taylor (2011); Gómez García (2015).

${ }^{41}$ Aguirre Salvador (2014, pp. 11-13); Morales (2010, pp. 50-52).

${ }^{42}$ El debate principal del Tercer Concilio Mexicano entre clero secular y frailes francisanos se enfocó en el pago de diezmo, la ampliación del tributo y el "régimen de limosnas de las doctrinas" que los obispos reclamaban como derecho precisamente desde la década de 1550. Véanse Tateiwa Igarashi (2016, pp. 147-149); Aguirre Salvador (2014); Morales (2010).

${ }^{43}$ El cobro de diezmos había sido prohibido en el Primer Concilio Mexicano y la mano de obra o servicio personal quedó bajo resguardo de la Corona, a diferencia de los frailes que podían obtenerlo a partir de sus vínculos con los caciques indios, con quienes establecieron alianza contra los encomenderos y los protegieron de otros abusos. Véanse Aguirre Salvador (2014); Menegus Bornemann (2010, p. 91).

${ }^{44}$ Estenssoro (2003); Aldana Rivera (2006). 
Regresaremos a este punto más adelante, cuando analicemos la estrategia recaudatoria de limosna de fray Diego de Ocaña.

Este presupuesto ayuda a explicar los beneficios económicos de las donaciones testamentarias de españoles y de sus viudas en los años subsecuentes a $1555,{ }^{45}$ que evidencian el éxito rotundo de la estrategia del arzobispo Montúfar para ampliar legítimamente su jurisdicción recaudatoria al consolidar la devoción de la imagen guadalupana en un pueblo de indios entre la feligresía hispana que, para 1541, eran en su mayor parte (88\%) viajeros oriundos de la región andaluza, extremeña o castellana, lugares con alta presencia del culto a Guadalupe. ${ }^{46}$ En conjunto, los legados testamentarios de españoles y la percepción de limosnas entre los indios permitieron que el arzobispado, encabezado por Montúfar, lograra armarse de un capital político y económico que puede interpretarse como un incipiente impulso secularizador.

Lo sucedido posteriormente abona a sustentar este postulado. El exitoso flujo recaudatorio defendido por Montúfar trajo consecuencias de dimensiones trasatlánticas. La capacidad recaudatoria del arzobispo era de tal magnitud que pronto fue motivo de sospechas, lo cual se hizo manifiesto a través de una denuncia interpuesta por integrantes del propio cabildo catedralicio ante el Consejo de Indias, en 1562, que dio inicio de manera inmediata a un proceso contra el arzobispo por abusos en la administración de limosnas, de las que no quedaban exentas las provenientes del culto a la virgen de Guadalupe. ${ }^{47} \mathrm{Al}$ conocerse en la metrópoli la existencia de esta devoción guadalupana en el centro del virreinato novohispano, los monjes del Monasterio de Guadalupe prontamente hicieron valer sus prerrogativas reales y, una vez llegados a las Indias, iniciaron los procesos de levantamiento de informaciones preliminares de aquella advocación. En esta circunstancia fue que arribó en la década de los sesenta y setenta un procurador y fraile jerónimo elegido por el monasterio extremeño para llevar a cabo la misión de cobrar las rentas, donaciones y limos-

${ }^{45}$ No se descartan en ningún momento las contribuciones económicas que seguramente habrán hecho sus varios devotos indios; sin embargo, recalcamos la donación de españoles porque fue la que se disputó en la década de 1570, cuando por primera vez se reclamó el derecho legal a las limosnas y la adjudicación al monasterio de Extremadura de las rentas que generaba el culto del Tepeyac en el centro de la Nueva España, como veremos más adelante.

${ }^{46}$ Ocaña (2010, p. 15).

${ }^{47} \mathrm{El}$ proceso contra el arzobispo revelaba una serie de abusos en la administración de los recursos de la ermita, especialmente de sus limosnas. Véase Ruiz Medrano (1992). 
nas que se dieran a nombre de Nuestra Señora de Guadalupe por parte de sus devotos españoles en el reino de la Nueva España. Fray Diego de Santa María se incorporaba a esta coyuntura política justamente unos años después de que el arzobispo Montúfar saliera airoso de las acusaciones de fray Francisco de Bustamante, quien tuvo que silenciar sus quejas respecto del establecimiento del culto en el Tepeyac so pena de excomunión. ${ }^{48}$

En vísperas de la muerte del prelado, en la década de 1570, el fraile jerónimo comenzó a rendir informes al rey Felipe II dando cuenta de la gravísima serie de incumplimientos en los que habían incurrido algunos devotos de la ciudad de México. Éstos, en su opinión, atentaban tanto contra el Monasterio de Guadalupe, del cual el rey era patrón, como contra la devoción a la virgen de Guadalupe de los fieles cristianos en el Nuevo Mundo. ${ }^{49}$ En carta fechada el 12 de diciembre de 1574, daría cuenta del origen fraudulento de la ermita del Tepeyac señalando que, aproximadamente, hacía unos doce años (1562) "un hombre con un poder falso de nuestro Monasterio de Nuestra Señora de Guadalupe [...] recogió muchas limosnas y, manifiesta la falsedad de poder, se huyó". ${ }^{50}$

A este agravio añadiría que la iglesia allí fundada se mantuvo, luego de aquel fraude, en manos de ciertos mayordomos quienes, conociendo la fama portentosa de la Virgen, habían comenzado a administrar sus rentas y solicitar demandas forzosas defraudando y entibiando "la devoción que a aquella casa solían tener los vecinos de esta provincia", ${ }^{51}$ apropiándose ilegítimamente de las aportaciones obligatorias que los devotos españoles tenían con la virgen de Guadalupe. Este conjunto de denuncias apelaba a una serie de normas jurídico-canónicas que el monasterio y sus agentes sabían invocar para que la Corona les reconociese las prerrogativas que ellos poseían. Implícitamente, el discurso de Santa María hacía referencia a una tradición legal de patronazgo regio en donde se podía acusar al monarca de incumplimiento de las obligaciones de velar por el culto a la virgen de Guadalupe y su sostenimiento, cuya restitución debía ser urgentemente remediada con el otorgamiento de concesiones y privilegios a favor de los monjes jerónimos que permitiera la restauración del orden natural y justo de las cosas.

${ }^{48}$ O’Gorman (2016, p. 71).

${ }^{49}$ Archivo General de Indias (en adelante, AGI), Documento Mexicano 69, n. 3, en Cuevas (1922, pp. 493-494).

${ }^{50}$ Cuevas (1922, pp. 493-494). Nótese que el año señalado coincide con la fecha en que llegó la denuncia del cabildo eclesiástico de México contra Montúfar al Consejo de Indias.

${ }^{51}$ Cuevas (1922, pp. 493-494). 
En la interpretación legal del demandador, la denuncia del fraude de fundación y al que ocurría en ese momento debían ser solucionados si "su Majestad tomase a bien que, por parte de la casa de Guadalupe, se tomase la cuenta a los administradores y personas que han tenido cargo de esta casa [...] y lo pusiese en el concierto y orden que Vuestra Majestad fuese servido". ${ }^{2}$ Posteriormente, solicitó "que se quite el nombre de Nuestra Señora de Guadalupe, o que se traslade esta casa a otra parte y [...] trasladándola a buen sitio, se podría hacer un monasterio de la Orden". ${ }^{33}$ Este argumento se vería expuesto de manera mucho más explícita en una segunda misiva, fechada el 24 de marzo de 1575, en donde solicita que

estos daños y abusos no veo cómo se pudiesen remediar, sino siendo Vuestra Majestad de hacer merced al monasterio de Nuestra Señora Santa María de Guadalupe, de la administración de esta ermita, mandando que se sustente en el estado que ahora está o siendo servido mandar que la levante el monasterio la Orden del glorioso nuestro padre San Jerónimo. ${ }^{54}$

Esta serie de denuncias legales recibieron la pronta respuesta de Felipe II, ya que el 15 de mayo de 1575 emitió una real cédula dirigida al virrey Martín Enríquez, para que este último diera seguimiento a tales problemas. El virrey, atendiendo las instrucciones reales, realizó primeramente una pesquisa para luego proseguir con una visita a la ermita del Tepeyac en compañía del recién nombrado arzobispo Pedro Moya de Contreras. El virrey Enríquez rindió su informe en una carta fechada el 23 de septiembre de $1575 .{ }^{55} \mathrm{Al}$ hacer referencia a la administración de las limosnas de la ermita, el alter ego del rey afirmó que "siempre se ha hecho por los prelados", 56 debido a que "allí se fundó una cofradía en la cual dicen habrá cuatrocientos cofrades, y de las limosnas se labró una iglesia". ${ }^{57}$ Por ser este informe acorde con las ordenanzas y disposiciones del Concilio de Trento - que

${ }^{52}$ Cuevas (1922, pp. 493-494).

${ }^{53}$ Cuevas (1922, pp. 493-494). Nótese aquí el argumento del nombre "Guadalupe" de la advocación de la virgen del Tepeyac. Éste sirve como evidencia jurídica del traspaso de la jurisdicción de la orden jerónima sobre todas las reproducciones de la virgen de Guadalupe, asunto que analizaremos más adelante.

${ }^{54}$ Cuevas (1922, p. 495).

${ }^{55}$ AGI, Audiencia de México, 19, n. 158.

${ }^{56}$ AGI, Audiencia de México, 19, n. 158, f. 3r. Es decir, las autoridades eclesiásticas del clero secular.

${ }^{57}$ La cofradía era de españoles. Véase AGI, Audiencia de México, 19, n. 158, f. 3v. 
dejaban bajo jurisdicción de los obispos las licencias y la vigilancia de las cofradías-, el virrey no pudo dar un parte favorable a la solicitud promovida por fray Diego de Santa María para fundar un convento jerónimo en tal ubicación, esgrimiendo que a su juicio "para asiento de Monasterio no es lugar muy conveniente por razón del sitio y hay tantos en la comarca que no parece ser necesario". ${ }^{58}$

No obstante, esta visita al Tepeyac mostró la capacidad recaudatoria del culto guadalupano que se beneficiaba de la superposición de jurisdicción eclesiástica entre clero secular y regular, presente en el conflicto entre el arzobispo Montúfar y los franciscanos. Esta circunstancia provocó ciertos incidentes entre el virrey Enríquez y el arzobispo Pedro Moya de Contreras, concernientes a la administración de las rentas y limosnas que producía este culto. Inmediatamente después de su informe negativo a los intereses de los jerónimos, el virrey promovió ante el rey y el arzobispo una iniciativa para aprovechar los mencionados ingresos, que él consideraba que estaban yéndose hacia obras innecesarias, como lo era la fundación de otra parroquia que perpetuaba la ambigüedad de la jurisdicción recaudatoria que "el prelado quería, ni para españoles ni indios". ${ }^{59} \mathrm{El}$ virrey sugirió, para paliar esta irregularidad, que al ser las limosnas un vehículo del bien común, se deberían emplear en obras piadosas de ayuda a los "pobres del hospital de los indios que es el que mayor necesidad tiene [...] y que si esto no le pareciese se aplicase para casar huérfanas". ${ }^{60}$

Empero, este oportunismo contencioso dañaba los intereses del arzobispo Moya de Contreras quien, honrando la actitud de su predecesor, dejó saber contundentemente al virrey que esa percepción de rentas y limosnas no podía salir de su jurisdicción. Para ello, recurrió nuevamente a una estrategia que legitimara la administración de los recursos. Como narra Martín Enríquez en el citado reporte: "el Arzobispo ha puesto ya dos clérigos y si la renta creciese más también querrán poner otro, por manera que todo venía a reducirse en que coman dos o tres clérigos". ${ }^{11}$ Es evidente que el prelado estaba defendiendo los privilegios recaudatorios del clero secular, estrategia que ya había sido vislumbrada por el demandador Santa María, quien desde su segunda misiva al rey anticipaba que el punto en discordia era el arzobispo por tener la ambigua jurisdicción sobre las limosnas, y

\footnotetext{
${ }^{58}$ AGI, Audiencia de México, 19, n. 158, f. 3v.

${ }^{59}$ AGI, Audiencia de México, 19, n. 158, f. 3v.

${ }^{60}$ AGI, Audiencia de México, 19, n. 158, f. 3v.

${ }^{61}$ AGI, Audiencia de México, 19, n. 158, f. 3v.
} 
podía "contradecir y será posible que lo haga, porque parece interesado en alguna manera su oficio y dignidad". ${ }^{62}$ Es decir, el asunto recaudatorio se circunscribía a las competencias entre clero secular y regular.

Es importante resaltar que, en todo momento, los testimonios documentales muestran un conflicto principalmente sobre la recaudación de limosnas, lo que generó diversas estrategias que los actores enarbolaron para aprovechar la ambigüedad que el sistema jurídico-político de las Indias permitía. En consecuencia, los monjes desistieron de continuar enviando demandadores de manera directa a la Nueva España. En su lugar, los sucesores de fray Diego de Santa María fueron enviados a otras partes de las Indias en donde no enfrentarían tan arduo panorama, y en donde también tenían información respecto del establecimiento de devociones guadalupanas fuera de su jurisdicción. ${ }^{63}$ Por ejemplo, el padre fray Diego de Losar, profeso de Guadalupe desde 1563, fue enviado al virreinato del Perú alrededor del año de $1587 .^{64}$

Ante tal coyuntura es sorprendente que en todos estos procesos jurídicos no se argumentase la aparición milagrosa en el Tepeyac, sobre todo si consideramos que este fue el motivo central para diferenciar a la virgen de Guadalupe del Tepeyac de la de Extremadura en los escritos aparicionistas que empezaron a circular durante el siglo XVII. Es interesante notar que fue precisamente el debate sobre las prerrogativas recaudatorias el evento que impulsó, durante esa centuria, la separación entre ambos cultos. Mientras tanto, la devoción mantuvo su lento curso alejada de amenazas de apropiación jurisdiccional que no volverían a hacerse presentes sino hasta la llegada del nuevo siglo, cuando la irrupción de un segundo demandador volviese a poner en disputa a las autoridades eclesiásticas y reales, tema que atendemos en el siguiente apartado.

Nuevo siglo, nuevos demandadores: fray Diego de Ocaña

La historiografía del conflicto por las limosnas entre el demandador Santa María, el arzobispado mexicano, el virrey y el clero regular suele dar por concluido este episodio con la negativa del virrey a los intereses del

${ }^{62}$ AGI, Documento Mexicano 69, n. 3, en Cuevas (1922, p. 496).

${ }^{63}$ Aldana Rivera (2006, pp. 41-68).

${ }^{64}$ Peña (2007, p. 39). 
demandador Santa María. Empero, nueva información revela que inmediatamente después de esta coyuntura un actor aparentemente desconocido revitalizó y redimensionó esta disputa: fray Diego de Ocaña. Este fraile manchego es un personaje bien conocido en la historiografía sudamericana. ${ }^{65}$ Fue un demandador extremeño enviado al virreinato del Perú en compañía de su hermano de hábito fray Martín de Posada. A diferencia de sus predecesores, este demandador elaboró un diario manuscrito, sin título, donde registró los pormenores de su misión. ${ }^{66}$

Fray Diego de Ocaña lograría realizar hazañas formidables en su corta estancia en el virreinato peruano y, con posterioridad, en dos ciudades de la Nueva España. Esto debido a que no limitó su estrategia a recolectar las limosnas para remitirlas al monasterio - como habían hecho o intentado hacer sus predecesores Santa María o fray Diego de Losar- sino que tenía también la misión de difundir el culto guadalupano y, especialmente, establecer instituciones debidamente reglamentadas (cofradías) para que las rentas de esta devoción pudieran llegar de forma regular al monasterio extremeño sin la necesidad de enviar periódicamente costosos agentes al Nuevo Mundo. ${ }^{67}$ Además, a causa de una profunda crisis financiera que su casa hogar enfrentaba hacia finales de este siglo, ${ }^{68}$ era también la responsabilidad de este fraile y su compañero de viaje poner bajo la jurisdicción de los jerónimos los centros devocionales que la virgen extremeña tenía en Indias a manos de agustinos, dominicos o franciscanos, y en el caso novohispano, seculares.

Esta necesidad económica probablemente fue un factor para su designación de último momento. Su juventud y excelente formación artística influyó decisivamente para que fuera nombrado segundo en el cargo de procurador del monasterio, complementando la experiencia del ya maduro fray Martín de Posada. Esta decisión daría tempranos resultados desde los primeros pueblos

${ }^{65}$ Ocaña (1987, pp. 8-9). Agradecemos a Werner Thomas las facilidades para acceder a este material.

${ }^{66}$ El diario está resguardado con la nominación Relación del viaje de fray Diego de Ocaña por el Nuevo Mundo en la Universidad de Oviedo. Manuscrito digitalizado por la misma institución, paleografía del padre Álvarez, quien lo hizo público hacia mediados del siglo pasado. La edición crítica, corregida y aumentada es de Blanca López de Mariscal y Abraham Madroñal, y a éste haremos referencia en las páginas que siguen. Véase Ocaña (2010).

67 "De manera que todos los días anda un hombre por las calles y casas pidiendo para Nuestra Señora de Guadalupe, y lo que recoge se entrega a los mayordomos para que se junte para Castilla. Y desta suerte será limosna perpetua”. Véase Ocaña (2010, p. 306).

${ }^{68}$ Peña (2007, p. 40). 
panameños donde se asentaron, pues fray Diego comenzó a dar muestra de su energía para promover la devoción a la obra milagrosa de Guadalupe y para asentar por cofrades a todos los habitantes españoles de las ciudades por las cuales él y su acompañante pasaban. Mientras su hermano de hábito reposaba de los malestares físicos causados por el terrible viaje, el demandador Ocaña comenzó a cobrar inmediatamente las limosnas y a utilizarlas para continuar sus viajes y, también, para solventar los gastos de ambos agentes, redirigiendo buena parte para su casa hogar en España. ${ }^{69}$

Las enfermedades de fray Martín y su posterior fallecimiento terminaron sumiendo a fray Diego de Ocaña, como él mismo afirmó, en una enorme crisis que lo mantuvo al borde del fracaso. Para solventar esta circunstancia puso en acción el talento artístico que había desarrollado en el monasterio y comenzó a pintar imágenes de la virgen de Guadalupe. En más de una ocasión sus reproducciones pictóricas estarían acompañadas, al momento de su donación a centros devocionales, por celebraciones litúrgicas en donde todas las cofradías de indios, negros y españoles participaban. Además, asistiéndose de las limosnas recolectadas y en especial de las joyas más preciadas de las naciones peruanas, adornó sus creaciones de tal manera que pudiera "espantar" a quienes las viesen, generando una impresión súbita de admiración que posteriormente haría que los observadores sintieran mayor devoción. ${ }^{70}$ Su creatividad le permitió representar en sus imágenes a los naturales de las tierras sudamericanas, pues se tomó la libertad de pintar la tez de sus vírgenes de un color menos oscuro que la original, de manera que la adorasen más por ser "de su color", ${ }^{71}$ por lo que prontamente recibieron el nombre cariñoso de "La Gran Chapetona", o como explica él mismo, "señora nueva de la tierra". ${ }^{72}$

Al pasar por ciudades de relevancia en el virreinato peruano, supo establecer una dinámica política que le permitió entablar prontamente aliados, quienes le facilitaron llevar a cabo la venta y/o colocación de sus nuevas reproducciones, las cuales adquirieron rápidamente fama de ser "verdaderos

69 "Por espacio de tres meses que estuve en Panamá los ocupé en asentar por cofadres [sic] de nuestra Señora a toda la gente de la ciudad.” Véase Ocaña (2010, p. 93).

70 "A todos cuantos la ven espanta." Véase Ocaña (2010, p. 319).

71 "Y como yo la pinté un poquito morena, y los indios lo son, decían que aquella Señora era más linda que las otras imágenes, y la querían mucho porque era de su color.” Véase Ocaña (2010, pp. 247-248).

${ }^{72}$ Ocaña (2010, p. 242). 
originales". ${ }^{73}$ En esto se distanció de otros demandadores como fray Diego de Losar - a quien constantemente refiere cuando habla de la ineficacia de empresas previas- o Santa María en la ciudad de México, quienes acudían en solitario para realizar únicamente los cobros de limosnas y legados testamentarios, la toma de posesión de rentas y ermitas y, en general, un ordenamiento de la jurisdicción que le correspondía a la orden de San Jerónimo. En cambio, consciente de sus limitantes y de la necesidad que tenía su cenobio, Ocaña prefirió asegurar alianzas con numerosos grupos indianos antes que atacar frontalmente a los circuitos de poder consolidados. Sus aliados fueron beneficiados con las recaudaciones de un culto tan exitoso como terminó siendo el de Guadalupe en el Perú, y además le ayudaron constantemente a continuar la difusión de esta devoción que estaba bajo su cuidado.

A lo largo de su transitar por el Perú, algunos conventos franciscanos permitieron al jerónimo colocar su imagen en el altar mayor sin ningún coste o impedimentos, además de celebrar una procesión y, finalmente, servir de intermediarios en la administración de las limosnas y las rentas de Guadalupe a cambio de percibir una parte de tales ingresos. En el caso específico de estos templos, los franciscanos tuvieron garantizados un peso por cada misa que se realizara en sus iglesias a devoción de la virgen de Guadalupe. Como queda evidenciado, con la nueva estrategia no solamente resultaron beneficiados el fraile jerónimo y su monasterio, al dejar una imagen con devoción que les aseguraba una renta anual, sino también sus colaboradores que gozaban del amplio poder de la administración y recaudación de los ingresos que generaba la imagen pintada por el fraile manchego. ${ }^{74}$

El entendimiento de Ocaña de las dinámicas políticas indianas se acompañó del ejercicio y el apoyo oportunos de diversas autoridades políticas, quienes respaldaron la misión devota del jerónimo, que se veía favorecida en gran medida por la obligación y lealtad que le debían tener al patrono de tal culto: el rey. Encontraría ayuda por parte del virrey Luis de Velasco, hijo, así como de oidores de las Reales Audiencias, corregidores y

${ }^{73}$ Peterson (2014, p. 51). El argumento es también jurídico. Fray Diego de Ocaña no contaba con el permiso de realizar copias de la virgen de Guadalupe que traía consigo, pues seguía siendo una facultad exclusiva del monasterio extremeño. Por esta razón, el fraile justifica sus pinturas no como copias sino como "verdaderos originales", pues habían sido pintadas por un fraile del monasterio y su "burdo" pincel habría sido guiado por la delicadeza de la voluntad de la virgen María.

74 "De suerte que el convento ni los frailes, no tienen sino la limosna de algunas misas que mandan decir algunas personas devotas, las cuales ansí como ansí nunca iban a España.” Véase Ocaña (2010, p. 230). 
un número considerable de cabildos peruanos. Esto permitió que fray Diego de Ocaña, a pesar de encontrarse en una situación similarmente adversa a la del citado Diego de Santa María, ${ }^{75}$ estableciera estrategias negociadoras para enfrentar los recelos de otros grupos de poder.

Ocaña optó por el poderoso recurso de la competencia corporativa y, en segunda instancia, litúrgica. ${ }^{76}$ Por ejemplo, el fraile estaba plenamente consciente de que pretender arrebatar la administración de las limosnas de Guadalupe a los padres agustinos, quienes tenían una famosa ermita de Guadalupe en el valle de Trujillo, sería complicado por no decir francamente imposible. ${ }^{77}$ En cambio, negoció con sus aliados políticos las comisiones necesarias para generar imágenes más famosas y milagrosas en ciudades y centros de culto aledaños, con lo cual logró de una manera menos desgastante y más eficiente "quitarles el comer" a los frailes agustinos, quienes terminaron administrando una reproducción de bulto de la virgen de Guadalupe menos "milagrosa". ${ }^{78}$ Otra estrategia relevante de fray Diego fue aprovechar para sus intereses la competencia entre ciudades vecinas, por lo que buscó disminuir la fama de las otras imágenes en favor de los "verdaderos originales" que él pintaba para restar importancia devocional a los centros que se hallaban fuera del control de su monasterio $\mathrm{y}$, en consecuencia, de aquellos santuarios bajo administración de otras órdenes o clero secular.

Este modus operandi solía sustentarse en una serie de procedimientos, los cuales permiten analizar sus estrategias políticas tanto en el cono sur como en la Nueva España. Primeramente, se presentaba ante los máximos poderes locales, tanto reales como eclesiásticos, donde hacía presentación de la real cédula con que venía acreditado, y solicitaba que se le extendieran permisos para asentar cofrades de Guadalupe. En el mismo tenor y circunstancia, pedía nombramientos de comisionados para que lo auxiliasen en tal recaudación piadosa. En obedecimiento a la orden real, el cabildo, el virrey o la audiencia nombraba con poderes cumplidos a uno o varios mayordomos para que acompañasen a fray Diego en su misión, asentando copia notariada de dichas reales ordenanzas para que

${ }^{75}$ O’Gorman (2016, p. 33).

${ }^{76}$ Aldana Rivera (2006).

77 "A los frailes yo no les podía quitar su casa ni su imagen." Véase Ocaña (2010, pp. 305-306).

78 "Ha sido de suerte que les he quitado a los frailes agustinos, como ellos dicen, el comer”. Véase Ocaña (2010, p. 305). 
las autoridades locales pudieran nombrar, en caso de ausencia de mayordomo, a un sustituto. Finalmente, Ocaña tomaba cuenta de lo que recaudaban sus demandadores nombrados y, al mismo tiempo, solicitaba tanto a los ayuntamientos como a los representantes del rey que supervisaran las cuentas de los libros de cofrades que éstos debían llenar. De paso, los llamaba también a poner el ejemplo para el resto de sus gobernados y, de esta manera, ser los primeros en asentarse por cofrades de Nuestra Señora de Guadalupe y ligarse a aportar cuantiosa limosna. ${ }^{79}$

Al pasar por cada ciudad, el fraile fue relatando en su diario sus acciones. En primer lugar, describió las condiciones climáticas, económicas y geográficas de las ciudades y sus territorios, para inmediatamente después asentar el número de cofrades, que eran las más de las veces la totalidad de la población de españoles de una ciudad o villa. ${ }^{80}$ De esta manera logró analizar la capacidad económica de cada región y adecuar sus estrategias con base en este criterio. En consecuencia, registró meticulosamente los montos del cobro de limosna y el subsecuente nombramiento de mayordomos. Éstos, con los poderes derivados de las reales cédulas y sus copias signadas de escribano, se convertían en agentes propiamente nombrados del Monasterio de Guadalupe. Dicho de otra forma, los aliados de Ocaña se convertían en demandadores empoderados para recolectar limosna $\mathrm{y}$, en el proceso, recibían una parte importante de lo recaudado como retribución, por lo que tenían facultad de cobrar y recolectar casa por casa, diariamente o cada sábado durante un año, para después remitirlas al Monasterio Real en Extremadura en la primera flota luego de pasar supervisión administrativa real o concejil. ${ }^{81}$

79 "Y puesto todo por buen orden, tomé el libro con el mayordomo nombrado y fuime al Virrey y pedile que se asentase por cofrade de Nuestra Señora para que los demás miembros fueran siguiendo a la cabeza, como lo hicieron. Y luego por su orden y antigüedad fui asentando a todos los oidores, y todos lo fueron firmando y rubricando; y lo mismo hizo el arzobispo y los inquisidores." Véase Ocaña (2010, p. 142).

80 "Por espacio de tres meses que estuve en Panamá los ocupé en asentar por cofadres [sic] de nuestra Señora a toda la gente de la ciudad.” Véase Ocaña (2010, p. 93). “Acabada de asentar toda la ciudad por cofadres [sic], por el orden dicho, traté luego de hacer una imagen de nuestra Señora de Guadalupe [...]." Véase Ocaña (2010, p. 143). "Después de que acabé de asentar por cofrades a toda la ciudad de Lima [...]." Énfasis nuestro. Véase Ocaña (2010, p. 159).

81 "Dejo puesto en Lima un hombre [Blasco Fernández de Toro] que todos los días pide por las calles para nuestra Señora de Guadalupe, y toda esta limosna es para España." Véase Ocaña (2010, p. 143). "Los mayordomos, que son tres regidores, piden para nuestra Señora de Guadalupe el sábado de cada semana, y cada vez que piden juntan diez ducados, de 
En este sentido, el diario de fray Diego constituye un memorial de méritos tanto de su persona como de quienes colaboraron en obediencia a la orden real, lo que era una estrategia conocida por los oficiales reales por ser un recurso legal importante para solicitar con posterioridad nuevas prebendas. ${ }^{82}$ El mismo Ocaña demandó reiteradamente mayores atribuciones jurídicas en retribución al servicio que prestaba, con informes detallados sobre la situación que guardaban zonas tremendamente conflictivas y disputadas en las fronteras del imperio. Sin embargo, la Corona se mostró siempre cautelosa al otorgar poderes a esta empresa, lo que queda de manifiesto en la terminante restricción que el monarca impuso a los demandadores respecto de la jurisdicción del establecimiento de cofrades, puesto que el soberano solamente les dio poder a estos agentes para asentar a españoles como cofrades de Guadalupe y bajo ninguna circunstancia a indios. De esta manera la Corona mantuvo estricto control sobre la recaudación en las Repúblicas de Indios.

La cédula real otorgada a fray Diego de Santa María en 1572 para establecer cofradías en Indias, con cuya copia (sacada en 1598) arribó a la ciudad de México fray Diego de Ocaña en 1606, muestra explícitamente tal limitante legal: "les dejéis coger las limosnas que se dieren y ofrecieren para la dicha casa con tanto que no se entienda ahora con los indios sino solamente con los españoles". ${ }^{83} \mathrm{El}$ fraile Ocaña dejó constancia de su disgusto por esta medida en su diario, esgrimiendo que los españoles en los reinos del Perú, fuera de las grandes ciudades, eran pocos y pobres. Por ello, expone que "y, si como la cédula del rey decía que el asentar cofrades se entendiese solo con los españoles, no tratara dello sino que lo callara, fuera más la limosna de los naturales, que la de los españoles". ${ }^{84}$ En otras palabras, el

suerte que toda esta limosna que se junta entre año, todo es para España.” Véase Ocaña (2010, pp. 230-231).

${ }^{82}$ El diario de Ocaña es un registro pormenorizado de los sujetos obligados a entregar cuentas sobre las limosnas, en el que citó con detalle a los mayordomos nombrados en las ciudades más importantes: Paita, Lima, Potosí, Chuquiabo. Además, registró a todos los representantes del rey y sus justicias que se encargarían de supervisar las cuentas: el virrey Luis de Velasco; el presidente de la Audiencia de Charcas y familiar del Santo Oficio; los corregidores de Cusco, Potosí, Yanqui; don Gaspar de Zúñiga y Acevedo, conde de Monterrey, virrey sucesor; y los obispos que le extendieron licencia de recolección en Lima, fray Toribio Alfonso Mogrovejo, posteriormente canonizado, y en Charcas, Alonso Ramírez de Vergara.

${ }^{83}$ Archivo General de la Nación (en adelante, AGN), Reales Cédulas Duplicadas, vol. D5, exp. 269, ff. 68v-69. Énfasis en cursivas nuestro.

${ }^{84}$ Ocaña (2010, p. 242). 
fraile reconoció lo relevante que resultaría tener privilegio recaudatorio entre los numerosos indios por ser feligresía mucho más grande que la de los devotos españoles en territorio indiano. Esta evaluación del fraile nos remite a la estrategia desplegada por el arzobispo Alonso de Montúfar en la ciudad de México, que contribuye a sustentar nuestra propuesta.

De forma similar al arzobispo Montúfar años antes en México, el fraile recaudador encontró una manera exitosa de sortear esta limitante jurisdiccional: venderles imágenes de la virgen a los indios sin contravenir las reales ordenanzas. La estrategia consistía en ofrecerlas en medio de fiestas y procesiones solemnes en donde los indios participaban. Aparentemente, esta venta de imágenes no fue penada o limitada por las autoridades locales, ya que aquéllas eran consideradas vera efigie al haber sido creadas en cercanía con la original. ${ }^{85}$ Por esta razón solicitó a su monasterio las veinte o treinta mil estampas de la virgen de Guadalupe que habían sido retrasadas a su viaje, para venderlas a los naturales a peso de ocho reales, puesto que ya había vendido todas las pocas con las cuales había partido. Lamentablemente para el fraile, al no enviarle su monasterio las decenas de miles de estampas que tanto solicitaba, se perdió una enorme oportunidad para recolectar hasta treinta mil pesos de parte de los devotos indios de los reinos del Perú ${ }^{86}$ Esto último pudo ser uno de los motivos para modificar su trayecto de regreso a España y decidir embarcarse hacia la Nueva España en búsqueda de otros ingresos, limosnas y rentas, colocando este reino como su última parada antes de poder regresar con éxito a su casa hogar en las Villuercas.

Desconocemos los motivos que orillaron a Diego de Ocaña a cambiar sus planes originales de viaje y tomar la decisión de emprender su fatal destino a la ciudad de México; sin embargo, podemos analizar algunas circunstancias que bien pudieran iluminarnos al respecto. En el virreinato del Perú, fray Diego tuvo a un poderosísimo aliado, quien inmediatamente antes de conocerlo había ejercido el máximo puesto de representación regia en la Nueva España: el virrey Luis de Velasco, el joven (1590-1595).

${ }^{85}$ La invocación a la "verdadera efigie", "verdadera imagen" o "verdadero retrato" es constante en las representaciones de imágenes sagradas, aludiendo a su cercanía con la imagen original ya sea por procedencia o por imitación plástica, de lo cual dependía también su milagrosa intervención en los rituales de intercesión.

86 "Si a esta sazón tuviera yo en Potosí, sobre la mesa donde estaba veinte mil a treinta mil estampas, todas las gastara, porque cada uno la llevara para tenella en su aposento; y por cada una lo menos que podían dar era un peso de plata.” Véase Ocaña (2010, p. 242). 
Fue precisamente el marqués de Salinas la primera figura de autoridad que reconoció en Perú los poderes otorgados a fray Diego, y también quien ordenó su acatamiento en 1599. Posteriormente, por propia iniciativa se incorporó a la cofradía de Guadalupe.

y puesto todo por buen orden, tomé el libro con el mayordomo nombrado y fuime al Virrey y pedile que se asentase por cofrade de Nuestra Señora para que los demás miembros fueran siguiendo a la cabeza, como lo hicieron. Y luego por su orden y antigüedad fui asentando a todos los oidores, y todos lo fueron firmando y rubricando; y lo mismo hizo el arzobispo y los inquisidores. ${ }^{87}$

Años después, este poderoso aliado tuvo que trasladarse otra vez a Nueva España al recibir el nombramiento de virrey para un segundo periodo, que comprendió de 1607 a 1611, habiendo de ser sustituido en el virreinato de Perú por el conde de Monterrey (1604-1606). En su diario, fray Diego de Ocaña registró, aunque de forma escueta debido a su convalecencia, su presencia en la entrada del nuevo virrey. ${ }^{88}$ Este testimonio es de gran relevancia, ya que de la misma manera en que hizo acto de presencia ante Luis de Velasco en 1599, "besándole las manos", 89 el fraile debió realizar contacto protocolario con el recién nombrado virrey Gaspar de Zúñiga y Acevedo a quien, asimismo, debió solicitar la ratificación de los poderes que ya habían sido reconocidos por su predecesor y asegurar asimismo las medidas de control respecto de las limosnas que se enviaban a Extremadura.

Lo que resulta relevante es que el conde de Monterrey, en su periodo como virrey de la Nueva España (1595-1603), había sido protagonista de otra querella jurisdiccional de un tono similar a la que se había vivido con el demandador Santa María en 1574. Gaspar de Zúñiga había conocido la problemática de las limosnas de Guadalupe en la ciudad de México, luego de que diera respuesta a una serie de órdenes que el rey le había encomendado en un corpus de reales ordenanzas. Entre ellas estaba un acatamiento que había realizado para que se nombrase a un miembro de la Real Audiencia "para tomar cuentas de la hacienda que acá tiene el Monasterio de Nuestra Señora de Guadalupe y dar orden en que se vendan los bienes como convenga. Y en que el dinero procedido se recoja y envíe". ${ }^{90}$ Aunque hasta el momento se

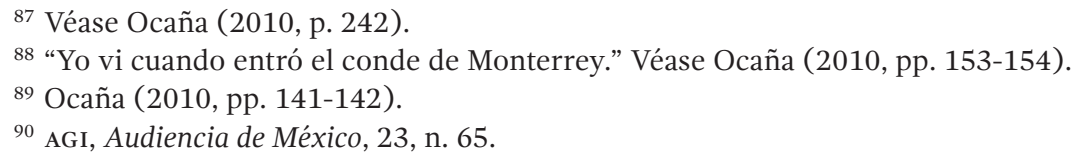


desconocen las consecuencias de tal medida, es esta circunstancia lo que hace del virrey conde de Monterrey un personaje con conocimientos previos concernientes a la demanda de limosnas en la ciudad de México. Muy probablemente también sería uno de los factores que orillarían a fray Diego, luego de su contacto con él, a tomar la decisión de arriesgar la vida y continuar con su empresa recaudatoria en los territorios del norte, toda vez que su anterior aliado, Luis de Velasco, el joven, se encontraba en camino para encabezar nuevamente el gobierno de la Nueva España (1607-1611).

Cuando fray Diego de Ocaña conoció al conde de Monterrey en Perú en 1604, el arzobispo de México era uno de sus hermanos de hábito, el jerónimo profeso de San Bartolomé Lupiana, fray García de Santa María Mendoza (1600-1606).${ }^{91}$ Este jerónimo fue quien colocó la primera piedra en la construcción para el traslado de la ermita de Guadalupe en el Tepeyac, ${ }^{92}$ misma que tiempo después fue bendecida por el arzobispo Juan de la Serna, del cual se derivó el famoso grabado del holandés Samuel Stradanus con el que fue difundida masivamente la imagen de Guadalupe a través de la impresión de diversas estampas devotas. ${ }^{93}$ El arzobispo García de Santa María pudo haber ofrecido sus vínculos a fray Diego de Ocaña hacia 1606, lo que probablemente explicaría la incursión del extremeño en una ciudad hasta ahora fuera del panorama del fraile: la Puebla de los Ángeles, como veremos a continuación. Hasta este momento el desarrollo de la investigación nos impide aseverar que alguno de los anteriores factores definiera la estrategia de fray Diego de Ocaña en la Nueva España. Empero, en conjunto, esta red vinculatoria y serie de eventos coyunturales pueden sentar los argumentos suficientes para interpretar el actuar de fray Diego. Por ejemplo, su decisión de viajar a Nueva España se registra tan sólo unas páginas después de describir su encuentro con el nuevo virrey conde de Monterrey. ${ }^{94}$

${ }^{91}$ Ocaña (1987, pp. 11-12). El arzobispo Pedro Moya de Contreras había fallecido en 1591.

92 Ocaña (1987, p. 25). La primera piedra fue colocada por el arzobispo Guerra, sucesor de García de Santa María, de acuerdo con Torre Villar y Navarro de Anda (1999, p. 91). Juan de la Serna fue un gran impulsor del proyecto secularizador, al igual de Montúfar, razón por la cual resulta del todo relevante que haya sido precisamente él quien consolidó la construcción de la ermita y difundió la devoción guadalupana.

${ }^{93}$ Mayer (2010, p. 38). No hay consenso entre los historiadores sobre la elaboración de esta imagen; sin embargo, podemos afirmar que es una imagen que ya revela signos iconográficos claros de las imágenes posteriores de la virgen, entre ellos el vínculo indisoluble del Tepeyac con la imagen.

${ }^{94}$ Ocaña (2010, p. 159). 
La manzana de la discordia: la competencia por limosnas entre México y Puebla de los Ángeles

Hacia la navidad del año 1605, fray Diego de Ocaña se embarcó a la Nueva España. ${ }^{95}$ A partir de ese momento dejó a sus biógrafos con un gran vacío informativo sobre sus postreras acciones, que se refleja en el silencio historiográfico sobre su empresa en los territorios septentrionales. ${ }^{96} \mathrm{El}$ margen temporal en el cual fray Diego pudo haberse movilizado, según la fecha de su muerte, fue relativamente reducido: menos de tres años (1606-1608). Por esta misma razón, y por el estado convaleciente en que reportó haber estado con anterioridad, los historiadores no han puesto atención en su obrar cuando éste arribó a la Nueva España. El 21 de octubre de 1606, fray Diego de Ocaña se presentó ante el virrey Juan de Mendoza y Luna, marqués de Montesclaros (1603-1607), para solicitar el cumplimiento y acatamiento de dos cédulas que le permitían la recolección de limosnas en este territorio, mismas que el virrey acató, mandó cumplir y, por supuesto, copiar en sus libros de forma protocolaria.

En la primera de las cédulas reales presentadas, emitida en Madrid el 17 de enero de 1596, el rey mandó que sus justicias en los reinos de ultramar nombrasen a una "persona honrada y de mucha confianza" para que ésta recogiera las limosnas que los devotos hacían a la virgen de Guadalupe y las remitieran a su casa, el Monasterio de Guadalupe en los reinos de Castilla, por estar estos últimos en problemas económicos debido a los enormes gastos que tenían "con la hospitalidad y otras obras pías que en

${ }^{95}$ Al final de su relación sitúa su embarque en el año 1604; sin embargo, su descripción de un auto inquisitorial celebrado el año siguiente prueba que esto se trata de un error. Por lo anterior, no pudo haber salido del virreinato peruano sino hasta 1605. Ante el desconocimiento del verdadero día de su salida, se mantiene la noción temporal de "pascua de navidad" que cita en el mismo diario para dar al lector un margen cronológico con el cual ubicar al viajero. Terminó su relación de viaje con las oraciones "voy embarcando mi ropa para caminar a México. Dios me lleve con bien”. Véase Ocaña (2010, pp. 503-504). Nótese que no dice a Nueva España, sino "a México", refiriendo sus intenciones de acudir específicamente a la capital del virreinato. Esto abona al argumento de que no contemplaba en su estrategia la ciudad de Puebla de los Ángeles.

${ }^{96}$ Ocaña (1987, p. 26). Gracias a historiadores contemporáneos del Monasterio de Guadalupe, sabemos que el manchego falleció algún día del año 1608. Una placa en el antiguo cenobio de Extremadura cita específicamente el 17 de noviembre de 1608, como la fecha en que se conoció su muerte "en Indias", además de que se hizo "por él oficio de presente, septenario, treintanario y cabo de Año". Véase López de Mariscal y Madroñal (2010, p. 14); y Álvarez (1987, p. 25). 
ella se hacen". ${ }^{97}$ Podemos observar que el asunto de la jurisdicción de las limosnas del culto a la virgen de Guadalupe, de acuerdo con Ocaña, estaba lejos de haber sido resuelto, ya que esta misma real cédula había autorizado el paso de religiosos demandadores a la Nueva España para que cobraran las limosnas y asentaran por cofrades a los españoles que así lo deseasen: "por otra mi cédula fecha en veinte y seis de mayo del año pasado de mil y quinientos y setenta y dos". ${ }^{8}$ A pesar de lo cual "ahora por parte del prior y frailes del convento de la dicha casa se me ha hecho relación que por no haber en esos reinos el orden que en éstos en recoger las limosnas y mandas que hacen a aquella casa, no solo no le son de provecho pero algunas personas y comunidades sin tener poder ni orden de ella recogen las dichas limosnas y se quedan con ellas".99

Esta es una clara referencia a las quejas y argumentos que en aquellos años había realizado fray Diego de Santa María con sus dos misivas. En consecuencia, el rey dispuso nuevos mandamientos para asegurar el correcto ordenamiento de las limosnas de Guadalupe en "esos reinos", bajo la supervisión de uno de sus procuradores con poder amplio y cumplido, como lo era fray Diego de Ocaña. Esta resolución real debía ser cumplida a través de un procedimiento ya analizado en el apartado precedente: la toma de asiento de cofrades de Guadalupe por parte de los mayordomos nombrados, la supervisión de las rentas recolectadas por parte de los jueces y audiencias reales y, finalmente, la emisión de informes minuciosos realizados por ambas partes que serían enviados a los religiosos del monasterio extremeño y, en este caso, vistas de primera mano por su procurador Ocaña. ${ }^{100}$

La segunda cédula real presentada por Ocaña al virrey Montesclaros señalaba las irregularidades en el cobro de limosnas y confirmaba la legalidad de la obra del demandador respecto del asiento de cofrades de Guadalupe. Esta real ordenanza había sido emitida en San Lorenzo el Real el 26 de mayo de 1572, inserta en la cédula anterior, y había sido mandada "sacar de mis libros por duplicada en Madrid a diez y seis de noviembre de mil y quinientos y noventa y ocho años” para la misión de Ocaña y Posada en Perú. Con ella, el demandador Ocaña solicitó que no interrumpiesen, como habían hecho ya con anterioridad, la urgente labor de recolección de limosnas y el asiento de cofrades en los reinos de Indias. En

\footnotetext{
${ }^{97}$ AGN, Reales Cédulas Duplicadas, vol. D5, exp. 267, ff. 68-68v.

${ }^{98}$ AGN, Reales Cédulas Duplicadas, vol. D5, exp. 267, ff. 68-68v.

${ }^{99}$ AGN, Reales Cédulas Duplicadas, vol. D5, exp. 267, ff. 68-68v.

100 AGN, Reales Cédulas Duplicadas, vol. D5, exp. 267, ff. 68-68v.
} 
obedecimiento a estas reales cédulas y a las solicitudes que el procurador Ocaña realizó, el virrey Juan de Mendoza y Luna reconoció la falta de aplicación de justicia que se realizaba en el caso de la obstrucción de la recolección de limosnas de Guadalupe, y ordenó el nombramiento de un mayordomo honrado quien realizaría la percepción de limosnas en la ciudad de México, supervisado siempre por él y por el procurador Diego de Ocaña, por lo cual "nombraba y nombró para los efectos [...] a Alonso Díaz de la Barrera, correo mayor de esta Nueva España, y así lo proveyó y firmó su excelencia”. ${ }^{101}$

Durante aproximadamente siete meses -de octubre de 1606 hasta abril de 1607-, Díaz de la Barrera estuvo encargado de solicitar conjuntamente con fray Diego de Ocaña las limosnas obligatorias que los cofrades de la ciudad de México ofrecían a la extremeña imagen de Guadalupe. Además, Díaz de la Barrera se comprometió, estuviera el fraile a su supervisión o no, a realizar esta labor anualmente tal como había ocurrido en Perú. A pesar de que no tenemos, hasta el momento, testimonio de todo lo obtenido por los demandadores por concepto de limosna a Nuestra Señora de Guadalupe entre 1606 y 1607, o en años posteriores, sabemos que los bienes de fray Diego al momento de su fallecimiento en Nueva España (1608) ascenderían a la considerable cantidad de "dos mil y quinientos y ocho pesos y un tomín”, ${ }^{102}$ de los cuales, muy seguramente, buena parte la constituyó lo obtenido por demanda de limosna en la ciudad de México y en la de Puebla

${ }^{101}$ AGN, Reales Cédulas Duplicadas, vol. D5, exp. 268, f. 68v. Alonso Díaz de la Barrera, vecino de la ciudad de México, había obtenido el puesto de correo mayor desde 1604 a través de una subasta, luego de que la vacante dejada por Martín de Olivares a su muerte diera lugar a la venta del oficio, ofertando entonces a la Real Hacienda la impresionante cantidad de 58000 pesos de oro común. Véase Archivo Histórico de la Ciudad de México (en adelante, Ансм), Acta de Cabildo del 13 de septiembre de 1604, libro xv, años de 1602-1604. Obtuvo el puesto perpetuo de correo mayor de la Nueva España y de sus provincias, que además conseguiría heredar a su hijo Pedro Díaz de la Barrera algunos años después. Además, por solicitud suya, también habría obtenido un asiento en el cabildo de la ciudad como regidor, esto a pesar de las varias quejas que interpuso el cuerpo ante el virrey contra esta medida. Véanse sesiones del 31 de julio y 5 de agosto de 1604, Ансм, libro xv. Para el tiempo en que conoció a fray Diego de Ocaña, entonces como representante de la ciudad que era, Alonso Díaz de la Barrera había recibido ya el nombramiento de obrero mayor del agua y también el de propios de la ciudad. Véase Ансм, libro xv, sesiones del 18 de enero y 19 de mayo de 1606.

102 AGI, Contratación, 282A, n. 1, r. 11, f. 3r. Sirva de referencia la cifra de 4000 pesos que la administración diocesana de la ermita de Guadalupe recibía anualmente en 1574, según denunció fray Diego de Santa María en su primera misiva. Cuevas (1922, pp. 493-494). Fray Diego de Ocaña en el Potosí recolectó en tan sólo ocho días más de 4000 pesos de limosnas. Véase Ocaña (2010, p. 241). 
de los Ángeles (como veremos a continuación). Podemos especular que, de la misma forma en que obró el fraile manchego en los reinos del Perú, Ocaña y Díaz de la Barrera se encargarían de hacer las demandas casa por casa entre los vecinos españoles de la capital novohispana con lo cual el procurador jerónimo debió obtener amplios recursos para enviar al monasterio y, además, continuar con la empresa en una ciudad vecina en apogeo con población española: la ciudad de Puebla de los Ángeles.

Antes de entrar en el análisis de lo ocurrido en la ciudad de los Ángeles, recordemos que la ciudad de México ya poseía una devoción a la virgen de Guadalupe - que sin lugar a dudas era entendida jurídicamente por el fraile como una representación más de la advocación de Extremadura-. Asimismo, que la administración de sus rentas se encontraba bien defendida y aprovechada por el clero secular, que en ese momento estaba encabezada por un arzobispo jerónimo, quien había sido general de la orden en $1591 .{ }^{103}$ Pese a que esta parecía ser una coyuntura favorable a la labor del demandador, el 5 de octubre de 1606, año del arribo de fray Diego de Ocaña a la ciudad de México, murió el prelado. No obstante, las relaciones que este arzobispo jerónimo había establecido previamente con generosos devotos en la capital novohispana pudieron haber conducido a que fray Diego decidiera seguir su labor en la ciudad de Puebla de los Ángeles. A este presupuesto nos conduce la incursión en el escenario de la recolección de limosnas para la virgen de Guadalupe de Melchor de Cuéllar, regidor de la ciudad de los Ángeles desde 1601, quien en el año de 1605 fundó en las cercanías de la ciudad de México el santuario del Desierto de los Leones de los Carmelitas Descalzos, es decir, durante la administración del arzobispo jerónimo García de Santa María. ${ }^{104}$

Al presentar fray Diego de Ocaña las reales cédulas que lo acreditaban ante el cabildo de la ciudad de los Ángeles en 1607, fueron nombrados

${ }^{103}$ Sosa (1978, p. 44). La reedificación de la ermita guadalupana no era una obra de este arzobispo, sino del cuerpo capitular quien, ante la larga sede vacante que dejó la salida de Pedro Moya de Contreras, se había convertido en nuevo administrador del culto y sus limosnas.

${ }^{104}$ Sosa (1978, p. 46). La presencia de este regidor en la política poblana es singular, ya que el mismo cabildo angelopolitano en una solicitud que remitieron al virrey había decidido que fuese nombrado nuevo regidor por su enorme riqueza y méritos, ocupando el puesto dejado por el fallecido Alonso Gómez. Archivo General Municipal de Puebla (en adelante, AGMP), Actas de Cabildo, vol. 13, sesión del 8 de diciembre de 1601, f. 169. Melchor de Cuéllar juró como regidor perpetuo de la ciudad, cargo por el cual realizó un pago en las arcas reales de la ciudad de México por 5000 pesos de oro común. AGMP, Actas de Cabildo, vol. 13, sesión del 20 de diciembre de 1601, ff. 172-172v; AGI, Patronato, vol. 293, n. 24, ff. 7-7v. 
mayordomos el regidor Melchor de Cuéllar y Nicolás de Villanueva, de acuerdo con la sesión del 30 de junio de este año. ${ }^{105}$ Con esta acción dio comienzo una compleja estrategia de competencias que el jerónimo fray Diego de Ocaña había ejecutado exitosamente en Trujillo, ${ }^{106}$ y con la cual intentaba quitarle "de comer" a los capellanes que administraban la ermita de Guadalupe en el Tepeyac bajo la jurisdicción del arzobispado. Esta estrategia era resultado de su conocimiento de la ambigüedad en la aplicación de los derechos recaudatorios de la orden, por lo que otra batalla legal por las rentas y limosnas de Guadalupe como la librada fallidamente por Santa María sería desgastante e infructuosa. Conocedor de esta circunstancia y con la experiencia adquirida en el virreinato de Perú, el demandador optó por privilegiar la alianza y la mediación con agentes locales poderosos, como lo eran los regidores Melchor de Cuéllar, Nicolás de Villanueva o el correo mayor Alonso Díaz de la Barrera, para establecer así un juego político con el cual competir por las limosnas que se hallaban fuera de la jurisdicción de su orden.

Siguiendo la estrategia llevada a cabo en Trujillo, fray Diego se apegó en la Nueva España al modus operandi implementado en el cono sur. Por ejemplo, apeló a las prerrogativas de jurisdicción real con las cuales pudo nombrar a los comisionados en colaboración con las autoridades locales. Con estas acciones se puede suponer que Ocaña pretendía difundir en la Puebla de los Ángeles, sede episcopal, una imagen de la virgen de Guadalupe que, ante los ojos de sus devotos, tuviera muchos más grandes y efectivos poderes milagrosos, al estar más próxima a la primera manifestación sobrenatural que cualquier otra reproducción pintada en la Nueva España. Por tanto, las pinturas, estampas y, en general, la devoción que Ocaña proponía podrían gozar de una mucho mayor fama por su calidad de "vera efigie”. ${ }^{107}$ Además, fray Diego podía utilizar el recurso de una comedia de Nuestra Señora de Guadalupe - escrita por él mismo- con la cual representaba en una forma didáctica el origen de la Virgen y los muchos milagros

105 AGmP, Actas de Cabildo, vol. 14, ff. 45v-46v.

${ }^{106}$ La estrategia consistía en impulsar la devoción en una sede alterna, cercana y poderosa, con la cual competir por las virtudes de ser la imagen del fraile la más milagrosa por ser la "vera efigie".

${ }^{107}$ Peterson (2014, p. 51). El hecho de que no se sepa - hasta el momento- de la supervivencia de ninguna reproducción suya en la ciudad de México o en Puebla no puede negar tal opción, ya que en los reinos sudamericanos éstas tampoco han logrado subsistir al paso del tiempo, pero sí influyeron decisivamente en el éxito de la devoción guadalupana, tal como deja testimonio la devoción a Guadalupe llevada a cabo hasta nuestros días. 
que realizaba con sus fieles, los cuales el mismo Ocaña habría presenciado en su viaje al Perú. ${ }^{108}$ En ese contexto, su llegada a la ciudad de Puebla de los Ángeles representa un momento crucial en el devenir de la devoción guadalupana.

Hasta este momento habían pasado largas décadas del culto guadalupano que, según consenso de la historiografía, se mantenía en los alrededores de la ciudad de México como una devoción de alcance relativamente local. Un aspecto importante a resaltar es que, en los conflictos por limosnas, no había aún alusión alguna al milagro de la aparición en el Tepeyac que pudiera deslindarla claramente de la virgen de Guadalupe de Extremadura. La explicación de esta ausencia testimonial responde más bien al contexto de conflicto con el cual habría nacido este culto; esto es, a la seguridad económica que les brindaba a sus sostenedores estar circunscrita a la jurisdicción episcopal, con lo cual podían tener control efectivo de sus rentas, les pareciera o no a sus rivales, ya franciscanos, ya jerónimos. En esa coyuntura, el crecimiento de esta devoción en otros territorios implicaría para sus capellanes el peligro constante de una nueva disputa jurídica, en la cual, a diferencia de las libradas con anterioridad, no podrían tener condiciones favorables una vez que salieran del arzobispado.

Con la irrupción de fray Diego de Ocaña entre 1606 y 1607 se inició un nuevo conflicto. Esta nueva etapa de disputa jurisdiccional presentaba ciertas ventajas a la causa del monasterio y a sus posibles aliados en ciudades vecinas, como Puebla. A la espera de un análisis de mucha mayor profundidad sobre el proceder de los tres demandadores novohispanos que escapa al objetivo de este estudio, es claro que debido a los enormes beneficios económicos que aseguraba la recolección de limosnas, así como por las ventajas políticas a las que se adhería el discurso de obediencia devota y leal al católico rey, patrón del culto, estos mayordomos tuvieron una participación mayor en la difusión de Guadalupe extremeña en la Nueva España y desempeñaron, además, un papel central en el discurso de competencia que Ocaña estratégicamente planteó para desafiar el celoso control que tenía el arzobispado en la ciudad de México. La ciudad de los Ángeles, entonces, se había convertido en el escenario alterno de promoción de un culto guadalupano más cercano a los intereses del rey, en una ciudad que competía con la de México por los privilegios reales.

108 Ocaña (2010, pp. 247-248). 
La muerte de Ocaña un año después de su arribo a la ciudad de los Ángeles fue el momento coyuntural para el impulso del argumento aparicionista en el Tepeyac. Posiblemente el alto clero novohispano estaba enterado del enorme éxito que había tenido la estrategia del fraile jerónimo en el impulso de la devoción a la Guadalupe Extremeña llevada a cabo en el cono sur, especialmente a través de sus imágenes que habían despertado enorme devoción, aún vigente hasta nuestros días, en ciudades como Chuquisaca o La Plata (hoy Sucre, Bolivia), por citar un ejemplo. ${ }^{109}$ No es ninguna coincidencia que, justamente el año en que llegara el fraile a Nueva España, 1606, se realizara o se datara la primera reproducción plástica de la virgen de Guadalupe del Tepeyac de mano del pintor Baltasar de Echave y Orio, ${ }^{110}$ y que además fuera ésta la única de la época conocida hasta el momento que enfatizara iconográficamente los atributos que terminarían por separar a las vírgenes que hasta entonces eran objeto de una misma devoción y jurisdicción: la milagrosa impresión en la tilma de Juan Diego.

\section{El discurso de la desunión}

La referencia al debate aparicionista ha estado ausente en el desarrollo de este artículo porque consideramos que la concepción de esta serie de argumentos no puede entenderse en su justa dimensión sin considerar este conflicto por las limosnas. Aunque inconclusa, la obra de fray Diego de Ocaña en Nueva España no representó nada más un proceso breve y coyuntural, sino que introdujo un argumento jurídico y económico que logró, a través de la competencia política, que la virgen del Tepeyac y su milagro original fueran haciéndose de un espacio en el imaginario y posteriormente en la retórica novohispana. ${ }^{111}$ Postulamos, entonces, que el

${ }^{109}$ Rodríguez G. de Ceballos (2001, p. 28).

${ }^{110}$ Montes González (2004, p. 327); Wobeser (2015, pp. 173-227). Agradecemos a Iván Escamilla González la referencia de esta pintura. Pese al debate sobre la fecha de elaboración de la pintura, el argumento se sustenta igualmente en cuanto a que se incorporan los atributos que separan a ambas imágenes sagradas.

${ }^{111}$ De acuerdo con las recientes investigaciones llevadas a cabo por Gisela von Wobeser, hacia 1615 se registraron testimonios narrativos sobre las apariciones de la virgen de Guadalupe a un indio ( tilma, además de otros testimonios similares recogidos en 1620. Agradecemos a Gisela von Wobeser esta información. 
planteamiento de Diego de Ocaña está vinculado a los distintos factores políticos, administrativos y de competencia jurisdiccional sobre limosnas que impulsaron la conformación del argumento aparicionista, hacia mediados del siglo XVII, con el cual se daba respuesta a una cuestión de prerrogativas recaudatorias.

Poco tiempo después de que fray Diego de Ocaña desarrollara su estrategia de competencia devocional en las ciudades de México y Puebla de los Ángeles, el clero secular metropolitano dio muestra de su capacidad de respuesta. El arzobispo implementó una estrategia de difusión de la virgen a través de un impulso a sus representaciones plásticas: la citada pintura de Echave, la imagen que se veneraba en el Tepeyac, estampas devotas y una placa realizada por Stradanus, ${ }^{112}$ con motivo de la reconstrucción del tercer santuario mariano inaugurado unos años después con indulgencias por el arzobispo fray Juan de la Serna. Adicionalmente, fue en este momento cuando la tradición devocional registró de manera fragmentada aspectos de la narrativa sagrada aparicionista a un indio ${ }^{113}$ - característica que compartía con la devoción a la virgen de los Remedios-, ${ }^{114}$ y la estampación de la imagen en la tilma, elemento que daba mayor sacralidad a la imagen frente a otra cualquiera vera efigie de la virgen extremeña.

El impulso devocional del arzobispado requirió de un fundamento que marcara de una vez y para siempre la diferenciación entre las jurisdicciones recaudatorias de la devoción a la virgen de Guadalupe mexicana y extremeña. Pese a esta respuesta inicial a las acciones del fraile jerónimo, se requirieron más de dos décadas para que tal argumento jurídico-canónico esgrimiera con precisión el milagro de estampación de la virgen de Guadalupe en la tilma juandieguina, llevada a cabo en la navidad de 1531, por voluntad de la Virgen, por Dios, por los ángeles o por todos en trabajo conjunto, como debatirían en su abundante oratoria sagrada los predicadores novohispanos de décadas posteriores. ${ }^{115}$ Esta serie de eventos sobrenaturales dados a conocer a través de la imprenta —en la Imagen de la virgen María Madre de Dios de Guadalupe de Miguel Sánchez en 1648, y el Huei

${ }^{112}$ Montes González (2015, p. 52).

${ }^{113}$ De nueva cuenta, agradecemos a Gisela von Wobeser esta información.

${ }^{114}$ Miranda Godínez (2001). La narrativa milagrosa de la virgen de los Remedios a un indio antecede en su elaboración como argumento jurídico al de la virgen de Guadalupe. Considerando esto, la brecha temporal entre la intervención de Ocaña y el surgimiento de una tradición aparicionista se reduce significativamente.

115 Cruz (1660, f. 13). 
tlamahuiçoltica en 1649 por el capellán Luis Lasso de la Vega- daría paso no sólo a la primera gran explosión devocional guadalupana fuera de la ciudad de México ${ }^{116}$ sino, además, al argumento que dotaría de independencia jurídica al culto del Tepeyac del de todas las demás imágenes de Guadalupe a lo largo de la monarquía hispánica. A falta de más estudios sobre el contexto histórico que favoreció la impresión de estos importantes escritos, con la información hasta aquí analizada no argumentamos a favor ni en contra de datar la redacción de la tradición aparicionista contenida en el Nican mopohua en el siglo xvi; sólo enfatizamos que nunca apareció esta tradición en los argumentos jurídicos del siglo xvi y que, en cambio, fue a partir de la coyuntura aquí señalada cuando hay evidencias de que incursionó en el debate sobre el origen del culto.

Estas narraciones que reiteran a la capital novohispana como escenario de tales mariofanías son, antes que nada, una serie de argumentaciones jurídicas que tienen por objetivo deshacer los vínculos de esta imagen con la Guadalupe extremeña, que gozaba del patronazgo real, y elevar entonces la impresión del Tepeyac a una categoría jurídica nueva. En ella, la voluntad del rey y las prerrogativas que éste hubiese otorgado con anterioridad no podrían intervenir en la voluntad divina expresada a través de esta aparición, ya que el rey, señor natural de la tierra, no podía desafiar el orden revelado sino limitarse a interpretarlo, dictarlo y acatarlo como el máximo juez y protector de tal orden. ${ }^{117}$

Una lectura atenta a los primeros documentos guadalupanos del siglo XVII (que ameritan un estudio que rebasa los objetivos de este trabajo) permite observar esta separación jurídica con claridad. Es de especial atención destacar dos factores discursivos: la impresión divina, no pintada por ningún ser humano, y por tanto irrefutablemente de origen sobrenatural y, en especial para este argumento, la elección del nombre de Guadalupe para tal prodigio por parte de la propia virgen María. Si bien en el Nican mopohua se narran las apariciones de la virgen de Guadalupe a Juan Diego, es digno de mención la referencia explícita al nombre de Guadalupe como una elección de la propia virgen, puesto que este es el elemento más significativo de referencia al conflicto jurisdiccional por las limosnas en la Nueva España. En el testimonio del tío de Juan Diego, Juan Bernandino, la virgen María solicitó explícitamente ser nombrada

116 Ángel Cruz (inédito).

117 Garriga (2004, pp. 13-44); Lara Semboloni (2014); Rucquoi (2012, pp. 43-67). 
de Guadalupe: "auh ma huel yuh quimotocayotiliz, ma huel yuh motocayotitzinoz iz CENQUIZCA ICHPOCHTZINTLI SANTA MARIA DE GUADALUPE in itlazoixiptlatzin". ${ }^{118}$

Esta referencia nominativa está directamente relacionada con la queja que fray Diego de Santa María realizó en sus misivas de 1574 y 1575, y que fray Diego de Ocaña vino a reavivar entre 1606 y 1607 . Esto es, que al defraudar a través de la elección del nombre famoso y reconocido de la virgen de Guadalupe, los capellanes del Tepeyac incurrieron en una violación de la jurisdicción de la advocación que el rey, a través de su patronazgo, les había asignado a los monjes de Villuercas; motivo por el cual solicitaron: "que se quite el nombre de Nuestra Señora de Guadalupe". ${ }^{119}$ A partir de la incorporación del nombre de Guadalupe por medio de una mariofanía se integró a la tradición guadalupana un argumento jurídico que contradecía a los jerónimos, quienes habían reclamado durante siglos propiedad sobre todas las imágenes guadalupanas. Es decir, se independizó jurisdiccional y canónicamente una tradición devocional de la otra.

Dicho de otra forma, la elección del nombre y la impresión divina por decisión de la Virgen negarían todas las prerrogativas anteriores y darían espacio a que fueran generadas nuevas, así como a que se expandiera un culto nuevo. Además, algunos de estos impresos fungieron luego como principal arma argumentativa para solicitar las correspondientes prerrogativas ante el monarca o a la Sede Vaticana, ya para ser definida como fiesta de precepto, ya elevación de patronato. Esto es especialmente evidente en el proceso de legitimación que se promovió en 1666, para reconocer esta

118 "Y que así habrá de llamarla, así será nombrada su venerada imagen Siempre Doncella [Virgen] Santa María de Guadalupe”. Traducción de Tomás Amaya y Lidia E. Gómez García. Texto náhuatl del bachiller Lasso de la Vega (1649), conforme a la versión moderna (1978) del presbítero Mario Rojas Sánchez. Véase Nebel (1995, p. 367). Mayúsculas en el original. La traducción de Primo Feliciano Vázquez, 1926 (1931): “y que bien la nombraría, así como bien había de nombrarse su bendita imagen, la siempre Virgen Santa María de Guadalupe”. La traducción de Mario Rojas Sánchez, 1978: “y que bien así la llamaría, bien así se nombraría [énfasis nuestro]: La Perfecta Virgen Santa María de Guadalupe, su Amada Imagen”. Nebel (1995, p. 202). En traducción de Miguel León-Portilla: “así la llamará, así se nombrará, la del todo doncella Santa María de Guadalupe, su preciosa imagen”. Véase León-Portilla (2000, p. 103). Nótese que "siempre doncella [virgen]" alude al misterio de la Inmaculada Concepción, jurado por la monarquía hispánica en la segunda década del siglo XVII y de gran relevancia en este contexto por la temporalidad. La palabra ixiptla merece un análisis detallado que no podemos desarrollar en este estudio.

119 AGI, Documento Mexicano 69, n. 3. Reproducido en Cuevas (1922, p. 496). 
devoción como distinta de la de Extremadura, para lo cual se levantaron nuevas informaciones como documentos probatorios. Después, el argumento fundante lo constituyó la aparición milagrosa de la Virgen, con lo cual se buscó legitimidad retrospectiva de su jurisdicción hasta el siglo XVI y, con ello, se legitimó todo lo ya actuado desde tiempos de Montúfar, poniendo fin al conflicto que habían planteado los anteriores demandadores. Finalmente, el impulso de este argumento a través de los predicadores y teólogos, se perpetuaría en la publicación y la divulgación de los más famosos y trascendentales libros guadalupanos: Huei tlamahuiçoltica de Luis Lasso de la Vega; Imagen de la virgen María Madre de Dios de Guadalupe del bachiller Miguel Sánchez; Origen milagroso del santuario de Nuestra Señora de Guadalupe y la posterior Felicidad de México de Luis Becerra Tanco; Estrella del norte de México de Francisco de Florencia; y Relación de la Milagrosa Aparición de Mateo de la Cruz. ${ }^{120}$

La retórica de estos intelectuales explica claramente los motivos que hacen de la virgen de Guadalupe del Tepeyac un culto original, distinto al de Extremadura y privilegiado por encima de aquél, del de otros cultos en la Nueva España o, inclusive, en toda la monarquía hispánica. Esto, por supuesto, siempre acompañando su interés de expandir el culto a otras partes, inclusive en aquéllas donde su par ya ha estado presente, para ganar mayor fama y, en consecuencia, mayor caudal de rentas con destino a su milagroso santuario. Estas numerosas argumentaciones respecto de la divina impresión y el autonombramiento guadalupano tienen como objetivo inequívoco resaltar sus diferencias, por lo que no son nada más una suma de orgullos criollos e intelectuales, sino antes que nada el enaltecimiento de un culto que a través de su milagro se ha separado de la virgen de Guadalupe de Extremadura.

Léase con atención, para ilustrar este punto, el apartado final que le dedicó enteramente Mateo de la Cruz a los elementos de diferenciación de la virgen de Guadalupe respecto de su par extremeña, con motivo de la estampa de su imagen y la elección del nombre de Guadalupe por parte de la divina Virgen:

No es título, y vocación, que alguna persona por su devoción le pusiese; sino que la misma Santísima Virgen envió a decir al Obispo, que se llamase su Santuario: Santa

${ }^{120}$ Lasso de la Vega (1649); Sánchez (1648); Becerra Tanco (1666); (1675); Florencia (1895); Cruz (1660). 
María Virgen de Guadalupe. [...] Nombre, que nos hace luego volver los ojos al Santuario de la Virgen de Guadalupe de Extremadura en España; que es de una Imagen de la Madre de Dios [...]. Este es el Guadalupe Extremeño, cotéjese al Mexicano: aquella imagen fabricó San Lucas, esta o la pintó Dios, o se pintó la misma Virgen, o por lo menos la pintaron los Ángeles: allí de Roma se la enviaron a un arzobispo de Sevilla; aquí del Cielo a un arzobispo de México: allí estuvo soterrada seiscientos años, como sembrada para venir en su vocación doscientos años después de descubierta allá, a florecer como nacida acá, más de tres mil y cuarenta leguas: allá se apareció a un pobre Vaquero, acá a un Indio pobre; allá, y acá pidió templo; allá, y acá se le fabricó frecuentado, y devoto allá de Reyes, acá de Virreyes, y en ambas partes de frecuentes piadosos concursos de personas varias: allá y acá tiene tabernáculo fabricado de plata, y en ambas partes con jubileo plenísimo se celebra la fiesta titular, y en ambas partes se llama de Guadalupe. Que es vocablo arábigo, y quedó de los Moros en España, y quiere decir Río de lobos: allá será porque abundaba de ellos el puesto; y acá porque los lobos, si ven primero, quitan la voz, y si los ven primero a ellos se enronquecen, y ahuyentan; siendo los lobos, como dice Laureto figura de los demonios, a quien la Santísima Virgen siempre miró primero, para ahuyentarlos, y quiso que este puesto se llamase de Guadalupe: para dar a entender que con su presencia ahuyentó los lobos infernales de este puesto, y los enronqueció, y quitó la voz para que no diesen más respuestas a los idólatras. ${ }^{121}$

Como se puede apreciar, pese a que a través del milagro narrado en el Nican mopohua se establecieron los elementos de separación todavía hubo necesidad de continuar defendiendo este argumento debido a que el nombre de Guadalupe seguía siendo asociado, durante el siglo XvII, a la virgen María de Extremadura, quien durante siglos enteros gozó de una fama singular. Por esta razón era tan importante, como lo deja ver el fragmento de Mateo de la Cruz, distanciar no sólo jurisdiccionalmente a ambas advocaciones, sino también en el ámbito devocional y doctrinario.

Lamentablemente para nuestro entendimiento del desarrollo histórico del culto, este exitoso impulso haría que se olvidaran las anteriores disputas jurídicas del siglo XVI y principios del XVII, aunque el argumento de desunión aparicionista tendría su momento cumbre hasta una centuria después. Con miras a obtener mayor legitimación, este discurso haría retrospectiva la existencia de esta separación hasta fechas tan tempranas como 1531, no por coincidencia, también haciendo testigo de la mariofanía al primer representante del arzobispado (que ostentaba la jurisdicción guadalupana): fray Juan

${ }^{121}$ Cruz (1660, p. 13). Itálicas en el original. 
de Zumárraga. Proponemos, por esta razón, que los debates respecto de la existencia o ausencia de los testimonios aparicionistas en la primera mitad del siglo Xvi se deben en parte a la enorme cantidad de interpretaciones de lo que en su momento pretendió ser un argumento jurídico -insistimosretrospectivo, y a que mientras más fue avanzando el siglo, mientras más desaparecía del panorama histórico entre cientos de expedientes las ríspidas disputas jurídicas interpuestas por los demandadores fray Diego de Ocaña o fray Diego de Santa María, la brecha entre una y otra mariofanía se volvería irreductible.

Ya había advertido tempranamente fray Antonio de Huete en las Informaciones el peligro de colocarle el nombre de Guadalupe a la imagen de bulto que se tenía en el Tepeyac, ${ }^{122}$ quizá consciente de que podrían intervenir e intervinieron, atinadamente, las prerrogativas jerónimas para el cuidado de las rentas. Pensó que nombrar a esta devoción María de Tepeaca o Tepeaquilla en 1556 habría sido jurídicamente más propio. De haberse introducido para este momento el milagro de la estampación o el testimonio histórico del Nican mopohua, quizás habría sido impulsada esta imagen desde el momento mismo de su colocación en 1556 como una virgen distinta a la de Extremadura. Empero, por otra parte, quizá no habría logrado recibir el beneficio de la retórica sagrada que le permitió después ocupar el sitio de mayor preminencia política en el reino que la vio nacer, aunque de forma accidentada y enormemente disputada.

\section{Conclusiones}

En el transcurso del presente artículo no hemos querido sumarnos en ningún momento a los argumentos del conocido debate aparicionista. Tampoco hemos buscado agotar las posibilidades interpretativas de un fenómeno histórico tan complejo como el guadalupano. El objetivo ha sido analizar el aspecto jurisdiccional del culto con fuentes y perspectivas generalmente poco atendidas, durante una coyuntura política de enorme trascendencia para el desarrollo histórico del culto a la virgen de Guadalupe en la Nueva España: el conflicto por sus limosnas.

Este aspecto no es excepcional. La existencia de debates y conflictos jurisdiccionales por la administración de un culto o de sus rentas era un

${ }^{122}$ O'Gorman (2016, p. 78). 
asunto recurrente, puesto que la iglesia no era un cuerpo unificado y libre de conflicto de intereses. ${ }^{123}$ Debido a ello, este tipo de problemáticas en el patrocinio de las distintas imágenes sagradas y cultos eran frecuentes, especialmente en una monarquía católica que integraba un territorio tan extenso como diverso. ${ }^{124}$ Sobre todo, porque el culto divino requería -y requiere aún- forzosamente de la recaudación de limosnas para su sustento. De esta manera, no es posible pensar en alguna devoción novohispana sin el marco de una jurisdicción recaudatoria. A mayor devoción, mayor recolección de limosna y por ende conflictos por su administración.

En este artículo hemos tenido como objetivo analizar los factores recaudatorios de limosnas intrínsecos a la religiosidad, e insertarlos dentro de un debate historiográfico sobre la temática guadalupana. Este análisis se sustentó en el presupuesto que considera las distintas formas de recaudación de limosnas - forzosas y voluntarias- como una práctica política, ya que la fiscalidad en el régimen monárquico era un acto político. Postulamos que el conflicto jurídico y de competencia sobre las limosnas permite explicar la complejidad discursiva que la apologética implementó en el siglo XVII para desarrollar un argumento de separación del culto de Tepeyac del de Extremadura.

En ese sentido, hemos argumentado que el culto guadalupano y el debate suscitado con motivo de la recaudación de sus limosnas, por más local que fuese, se insertó en una coyuntura de alcances monárquicos. El estudio del culto guadalupano en la Nueva España aún requiere analizar con mayor detenimiento su relación con la contraparte extremeña y las batallas jurídicas que esta compleja vinculación ocasionó a finales del siglo XVI y principios del XVII, sobre todo en la administración de sus limosnas. En especial, le debemos al joven fray Diego de Ocaña y a sus predecesores mayor crédito en el desarrollo del culto guadalupano, del cual quisieron administrar sus rentas y cuyas acciones impulsaron - ¡vaya ironía! - lo que devino en la expansión monumental del culto ante el cual, finalmente, perdieron todo derecho de recaudación. En ese sentido, lo hasta aquí argumentado pretende despertar el interés sobre un aspecto poco estudiado, a fin de que los historiadores dirijan la mirada hacia la temática de la recaudación de limosnas puesto que, como hemos mencionado, además de constituir

${ }^{123}$ Lempérière (2013, pp. 49-50).

${ }^{124}$ Cardim, Herzog, Ruiz Ibáñez y Sabatini (2012, p. 5). 
un acto político, formaba parte de las complejas prácticas que sostenían a todas las devociones de la monarquía católica.

\section{FUENTES}

Archivos

AGI Archivo General de Indias

http://pares.mcu.es/ParesBusquedas/servlets/Control_servlet?accion $=4 \& t x t \_a c c i o n \_o r i g e n=2 \& t x t \_i d \_d e s c \_u d=360552$. Consultado el 27 de junio de 2016.

AGN Archivo General de la Nación

AACM Archivo del Ayuntamiento de la Ciudad de México

AGMP Archivo General Municipal de Puebla

Bibliografía

Aguirre Salvador, R. (2014). El Tercer Concilio Mexicano frente al sustento del clero parroquial. Estudios de Historia Mexicana, 51, 9-44.

Alberro, S. (1997). Remedios y Guadalupe: de la unión a la discordia. En Clara García Ayluardo y Manuel Ramos Medina (coord.), Manifestaciones religiosas en el mundo colonial americano (pp. 151-164). México: Universidad Iberoamericana/Servicios Condumex/Instituto Nacional de Antropología e Historia.

Aldana Rivera, S. (2006). Entre obreros del señor: conflicto y competencia por el control del santuario de Nuestra Señora de Guadalupe. Histórica, 30-2, 41-68. http://revistas.pucp.edu.pe/index.php/historica/article/download/355/344 (consultado el 15 de febrero de 2016).

Anales del barrio de San Juan del Río. Crónica indígena de la ciudad de Puebla, siglo XVII. Estudio introductorio y transcripción paleográfica de L. E. Gómez García, C. Salazar Exaire y M. E. Stefanón López. Puebla: Benemérita Universidad Autónoma de Puebla, Instituto de Ciencias Sociales y Humanidades/Consejo Nacional para la Cultura y las Artes, 2000.

Ángel Cruz, E. (inédito). ¿Patronato disputado o concurrido? Los patrocinios del culto a Nuestra Señora de Guadalupe en Puebla, siglo XVII. Texto presentado en el Coloquio Devociones Católicas en Iberoamérica, siglos XVI-XviII, México, Universidad Nacional Autónoma de México, Instituto de Investigaciones Históricas, 23 de agosto de 2017, en dictamen para publicación en libro coordinado. 
BARRAL, M. E. (1998). Limosneros de la Virgen, cuestores y cuestaciones: la recolección de la limosna en la campaña rioplatense, siglo xviII y principios del xIx. Boletín del Instituto de Historia Argentina y Americana "Dr. Emilio Ravignani", tercera serie, 18, 7-33. https://www.academia.edu/19731697/_Limosneros_de_la_virgen_cuestores_y_cuestaciones_La_recolecci\%C3\%B3n_de_la_limosna_en_la_campa\%C3\%B1a_rioplatense_siglo_XVIII_y_principios_del_ XIX (consultado el 8 de septiembre de 2016).

Becerra TANCo, L. (1666). Origen milagroso del santuario de Nuestra Señora de Guadalupe. México: Impr. y Litografía Española.

(1675). Felicidad de México en el principio, y milagroso origen, que tuvo el Santuario de la Virgen María N. Señora de Guadalupe. México: Viuda de Bernardo Calderón.

BRADING, D. (2002). La virgen de Guadalupe: imagen y tradición [primera edición 2001]. México: Taurus, 2002.

Calvo, T. (1997). El Zodiaco de la nueva Eva: el culto mariano en la América septentrional hacia 1700. En C. García Ayluardo y M. Ramos Medina (coord.), Manifestaciones religiosas en el mundo colonial americano. México: Universidad Iberoamericana/Servicios Condumex/Instituto Nacional de Antropología e Historia. https://www.academia.edu/13425774/El_Zodiaco_de_la_Nueva_ Eva_El_culto_Mariano_en_la_Am\%C3\%A9rica_Septentrional_hacia_1700 (consultado el 19 de junio de 2017).

Cardim, P.; T. Herzog; J. J. Ruiz Ibáñez, y G. Sabatini (2012). Polycentric Monarchies. How did Early Modern Spain and Portugal Achieve and Maintain a Global Hegemony? Brighton: Sussex Academic Press.

Chimalpahin Cuauhtlehuanitzin, F. de S. A. (1889), Annales de don Francisco de San Antón Chimalpahin Cuauhtlehuanitzin, sixième et septième relations (1268-1612). Trad. Rémi Siméon. París: Maisonneuve et Ch. Leclerc Ed.

Cruz, M. de la (1660). Relación de la milagrosa aparición de la santa imagen de la virgen de Guadalupe de México, sacada de la Historia que compuso el bachiller Miguel Sánchez. Puebla: Imprenta de la Viuda de Juan de Borja, y Gandia.

Cuevas, M. (1922). Historia de la Iglesia en México. Libro segundo: los elementos regeneradores. 1572-1600. México: Imprenta del Asilo "Patricio Sanz". https:// archive.org/details/historiadelaigle02cuev (consultado el 23 de junio de 2016).

Eichmann-Oehrli, A. (2004). La virgen extremeña de Guadalupe en Charcas. En I. Arellano y E. Godoy (eds.), Temas del barroco hispánico. Madrid: Universidad de Navarra/Iberoamericana (pp. 71-88), http://hdl.handle.net/10171/22491 (consultado el 23 de junio de 2016).

EsCAMILla GonZÁLez, I. (2010). La piedad indiscreta: Lorenzo Boturini y la fallida coronación de la virgen de Guadalupe. En F. J. Cervantes Bello (coord.), La Iglesia en la Nueva España. Relaciones económicas e interacciones políticas 
(pp. 229-256). Puebla: Benemérita Universidad Autónoma de Puebla, Instituto de Investigaciones Sociales y Humanísticas “Alfonso Vélez Pliego”.

(2000). Máquinas troyanas: el guadalupanismo y la ilustración novohispana. Relaciones. Estudios de historia y sociedad, 21, 199-232. http://www.redalyc.org/html/137/13708209/ (consultado el 21 de octubre de 2014).

Estenssoro, J. C. (2003). Del paganismo a la santidad. La incorporación de los indios del Perú al catolicismo, 1532-1750. Lima: Instituto Francés de Estudios Andinos/ Pontificia Universidad Católica del Perú, Instituto Riva-Agüero.

Florencia, F. de (1895), Estrella del norte de México. Guadalajara: Imprenta de J. Cabrera.

Fuentes Nogales, M. del C. (2008). Santa María de Guadalupe, cien años como patrona de Extremadura. Cauriensia, III, 507-521. http://dehesa.unex.es/bitstream/handle/10662/2215/1886-4945_3_507.pdf?sequence=1 (consultado el 28 de septiembre de 2015).

GARriga, C. (2004). Orden jurídico y poder político en el Antiguo Régimen. Istor, IV-16, 13-44. http://www.istor.cide.edu/revistaNo16.html (consultado el 28 de septiembre de 2015).

Gómez GARCíA, L. E. (2015). La devoción guadalupana de los nahuas poblanos, siglos XVII-XX. En D. M. J. Pérez Torres (comp.), Del imaginario social a la fe: Guadalupe (pp. 51-84). Puebla: Universidad Popular Autónoma del Estado de Puebla.

(2019). Los anales nahuas de la ciudad de Puebla de los Ángeles, siglos XVI y XVIII. Escribiendo historia indígena como aliados del rey católico de España. Puebla: Ayuntamiento de Puebla, Gerencia del Centro Histórico/Unesco/Universidad de Rutgers (versión impresa 2018, versión digital 2019). http://pueblacapital. gob.mx/images/LibroAnalesDigital.pdf (consultado el 19 de abril de 2019).

GonzÁlez FERnÁndez, F. (2004). Guadalupe: pulso y corazón de un pueblo. Madrid: Ediciones Encuentro. https://books.google.com.mx/books?id=IoKPFQ7dUCMC\&dq=primera+reproduccion+guadalupe\&source=gbs_navlinks_s (consultado el 19 de marzo de 2017).

Herrejón Peredo, C. (2003). Del sermón al discurso cívico: México, 1760-1834. Zamora: El Colegio de Michoacán/El Colegio de México.

Informaciones de 1556. Proyecto Guadalupe.com. http://www.proyectoguadalupe. com/PDF/infor_1556.pdf (consultado el 14 de abril de 2016).

JuÁrez, N. de J. (2018). San Juan Ixhuatepec y sus conflictos de tierras en la jurisdicción de Guadalupe. Tesis de maestría en Estudios Mesoamericanos. México: Universidad Nacional Autónoma de México.

LASSo DE LA VEGA, L. (1649). Huei tlamahuiçoltica omonexiti in ilhuicac tlatóca Çihuapilli Santa Maria Totlaçònantzin Guadalupe in nican huei altepenahuac Mexico itocayocan tepeyacac. México: Imprenta de Juan Ruiz. https://archive.org/ details/hueitlamahuiolti00lass (consultado el 17 de agosto de 2017). 
Lempérière, A. (2013). Entre Dios y el rey: la república. La ciudad de México de los siglos XVI al XIX. México: Fondo de Cultura Económica.

León-Portilla, M. (2000). Tonantzin Guadalupe. Pensamiento náhuatl y mensaje cristiano en el "Nican mopohua". México: Fondo de Cultura Económica/El Colegio Nacional.

Martínez Baracs, R. (2015). Notas sobre la elaboración del Nican mopohua. En M. del P. Martínez López-Cano (coord.), De la historia económica a la historia social y cultural (pp. 320-323). México: Universidad Nacional Autónoma de México.

(2014). La aparición del Nican mopohua. En P. Máynez, S. Reyes Equiguas y F. Villavicencio Zarza (coord.), Contactos lingüísticos y culturales en la época novohispana. Perspectivas multiculturales (pp. 369-396). México: Centro de Investigaciones y Estudios Superiores en Antropología Social/Universidad Nacional Autónoma de México, Instituto de Investigaciones Bibliográficas. https://www.academia.edu/22499188/la_aparici\%c3\%b3n_del_nican_mopohua (consultado el 16 de junio de 2017).

(2007). Tepeaquilla, 1528-1555. Historias, 49, 43-72.

(2003). Tepeyac en el Códice Tlatelolco. Estudios de Cultura Náhuatl, 34, 291-305.

Mayer, A. (2010). Flor de primavera mexicana. La virgen de Guadalupe en los sermones novohispanos. México: Universidad Nacional Autónoma de México, Instituto de Investigaciones Históricas.

(2002). El culto de Guadalupe y el proyecto tridentino en la Nueva España. Estudios de Historia Novohispana, 26, 17-49.

MAzA, F. de la (1981). El guadalupanismo mexicano. [Primera edición 1953]. México: Fondo de Cultura Económica.

Menegus Bornemann, M. (2010). La Iglesia de los indios. En M. Menegus Bornemann, F. Morales Valerio y Ó. Mazín Gómez, La secularización de las doctrinas de indios en la Nueva España. La pugna entre dos iglesias. México: Universidad Nacional Autónoma de México, Instituto de Investigaciones sobre la Universidad y la Educación.

Miranda Godínez, F. (2001). Dos cultos fundantes: Los Remedios y Guadalupe (1521-1649). Historia documental. México: El Colegio de Michoacán.

Montalvo, D. de (1631). Venida de la soberana virgen de Guadalupe a España, su dichosa invención y de los milagrosos favores, que ha hecho a sus devotos. Tomo primero. Lisboa: Pedro Craesbeeck.

Montes González, F. (2015). Sevilla guadalupana. Arte, historia y devoción. Sevilla: Diputación de Sevilla.

Morales Valerio, F. (2010). La iglesia de los frailes. En Margarita Menegus Bornemann, F. Morales Valerio y Ó. Mazín Gómez, La secularización de las 
doctrinas de indios en la Nueva España. La pugna entre dos iglesias (pp. 35-65). México: Universidad Nacional Autónoma de México, Instituto de Investigaciones sobre la Universidad y la Educación/Bonilla Artigas.

Moro Romero, R. (2012). ¿Una práctica poco visible? La demanda de limosnas "indígena” en la Nueva España del siglo XviıI (Arzobispado de México). Estudios de Historia Novohispana, 46, 115-172.

Nebel, R. (1995). Santa María Tonantzin, virgen de Guadalupe, continuidad y transformación religiosa en México. México: Fondo de Cultura Económica.

Noguez, X. (1995). Documentos guadalupanos. Un estudio sobre las fuentes de información tempranas en torno a las mariofanías en el Tepeyac. México: El Colegio Mexiquense/Fondo de Cultura Económica.

Ocaranza, F. (1944). Gregorio López, el hombre celestial. México: Xóchitl.

O'Gorman, E. (2016). Destierro de sombras: luz en el origen de la imagen y culto de Nuestra Señora de Guadalupe de Tepeyac. [Primera edición 1986]. México: Universidad Nacional Autónoma de México, Instituto de Investigaciones Históricas.

Ocaña, Diego de (2010), Viaje por el Nuevo Mundo: de Guadalupe a Potosí, 15991605. Edición de B. López de Mariscal y A. Madroñal. Madrid: Universidad de Navarra/Iberoamericana/Vervuert/Bonilla Artigas/Instituto Tecnológico y de Estudios Superiores de Monterrey (Serie Biblioteca Indiana, 22).

(1987). A través de la América del Sur. Edición de A. Álvarez. Madrid: Historia 16 (Serie Crónicas de América, 33).

PeÑA, B. C. (2007). Images of the New World in the Travel Narrative (1599-1607) of Friar Diego de Ocaña (vol. 1). Ann Arbor, Missouri: City University of New York, ProQuest Dissertations Publishing. http://search.proquest.com/docview/304888439 (consultado el 24 de junio de 2016).

Peterson, J. F. (2014). Visualizing Guadalupe: from Black Madonna to Queen of the Americas. Austin: University of Texas Press.

Reyes García, L. (2001). ¿Cómo te confundes? ¿Acaso no somos conquistados? Anales de Juan Bautista. México: Biblioteca Lorenzo Boturini, Insigne y Nacional Basílica de Guadalupe/Centro de Investigaciones y Estudios Superiores en Antropología Social.

Rodríguez G. De Ceballos, A. (2001). "Trampantojos a lo divino”: íconos pintados de Cristo y de la Virgen a partir de imágenes de culto en América meridional. En Actas III Congreso Internacional del Barroco Americano: Territorio, Arte, Espacio y Sociedad (pp. 24-33). Sevilla: Universidad de Pablo de Olavide.

Rucquoi, A. (2012). Tierra y gobierno en la península ibérica medieval. En Ó. Mazín y J. J. Ruiz Ibáñez (ed.), Las Indias Occidentales. Procesos de incorporación territorial a las monarquías ibéricas (pp. 43-67). México: El Colegio de México/ Red Columnaria. 
Ruiz Medrano, E. (1992). Los negocios de un arzobispo: el caso de fray Alonso de Montúfar. Estudios de Historia Novohispana, 12, 63-83. http://www.revistas.unam. $\mathrm{mx} /$ index.php/ehn/article/view/3365 (consultado el 8 de septiembre de 2017). SEMboloni, L. (2014). La construcción de la autoridad virreinal en la Nueva España, 1535-1595. México: El Colegio de México, Centro de Estudios Históricos.

SÁnchez, M. (1648). Imagen de la virgen María, madre de Dios de Gvadalupe, milagrosamente aparecida en la Ciudad de México. México: Imprenta de la Viuda de Bernardo Calderón. http://www.cervantesvirtual.com/obra/imagen-de-la-virgen-maria-madre-de-dios-de-gvadalupe-milagrosamente-aparecida-en-la-ciudad-de-mexico/ (consultado el 17 de agosto de 2017).

Sigaut, N. (2012). Los cultos marianos locales en Hispanoamérica. En Ó. Mazín (ed.), Las representaciones del poder en las sociedades hispánicas (pp. 437-439). México: El Colegio de México, Centro de Estudios Históricos.

Sosa, F. (1978). El episcopado mexicano. [Primera edición 1877]. México: Innovación. TAlavera, G. de (1597). Historia de Nuestra Señora de Guadalupe consagrada a la Soberana Majestad de la Reina de los Ángeles, milagrosa patrona de este santuario. Toledo: Casa de Thomas de Guzmán. https://play.google.com/store/books/ details?id=emE8AAAAcAAJ (consultado el 24 de junio de 2016).

TAteiwa Igarashi, R. (2006). La rebelión del marqués del Valle: un examen del gobierno virreinal en Nueva España en 1566. Espacio, Tiempo y Forma, 29, 135-161.

TAYLOR, W. (2011). Shrines and Miraculous Images: Religious Life in Mexico before the Reforma. Albuquerque: University of New Mexico Press.

Torre Villar, E. de la, y R. Navarro de Anda (1999). Testimonios históricos guadalupanos. [Primera edición 1982]. México: Fondo de Cultura Económica.

Wobeser, G. von (2015). Antecedentes iconográficos de la imagen de la virgen de Guadalupe. Anales del Instituto de Investigaciones Estéticas, XXXVII-107, 173227. http://www.analesiie.unam.mx/index.php/analesiie/article/view/2558/ 3111 (consultado el 19 de junio de 2017).

\section{SOBRE LOS AUTORES}

Lidia E. Gómez García. Doctora en Historia Moderna por la Universidad Libre de Berlín. Especialidad: etnohistoria en Nueva España, siglos Xvi al XIX. Publicaciones recientes en coautoría con Gustavo Mauleón Rodríguez, "La magnificencia del culto litúrgico y devocional en los pueblos de indios del obispado de Tlaxcala, siglos xvi y xvir: las capillas de música”, en Gustavo Mauleón Rodríguez, Miradas al patrimonio musical universitario. 
Solfas, letras, figuras y artilugios. Puebla: Benemérita Universidad Autónoma de Puebla, 2017, y Mantenimiento del culto divino. Los archivos de fiscales de Santa Inés Zacatelco (siglos Xvi al xviII). En Agustín René Solano Andrade e Israel León O’Farril (coord.), Zacatelco. Patrimonio y memoria. Puebla: Benemérita Universidad Autónoma de Puebla, 2017.

Eduardo Ángel Cruz. Estudiante de maestría en Historia del Centro de Investigación y Docencia Económicas. Especialidad: historia de la religiosidad e historia social en la Nueva España. 